Discussion Paper No. 13-116

\title{
ICT and the Demand for Energy: Evidence from OECD Countries
}

Sascha Rexhaeuser, Patrick Schulte, and Heinz Welsch

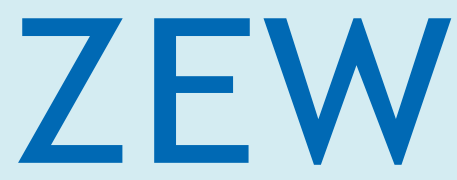

Zentrum für Europäische Wirtschaftsforschung $\mathrm{GmbH}$

Centre for European Economic Research 
Discussion Paper No. 13-116

\title{
ICT and the Demand for Energy: Evidence from OECD Countries
}

\author{
Sascha Rexhaeuser, Patrick Schulte, \\ and Heinz Welsch
}

Download this ZEW Discussion Paper from our ftp server:

http://ftp.zew.de/pub/zew-docs/dp/dp13116.pdf

Die Discussion Papers dienen einer möglichst schnellen Verbreitung von neueren Forschungsarbeiten des ZEW. Die Beiträge liegen in alleiniger Verantwortung der Autoren und stellen nicht notwendigerweise die Meinung des ZEW dar.

Discussion Papers are intended to make results of ZEW research promptly available to other economists in order to encourage discussion and suggestions for revisions. The authors are solely responsible for the contents which do not necessarily represent the opinion of the ZEW. 


\title{
ICT and the Demand for Energy: Evidence from OECD Countries*
}

\author{
Sascha Rexhaeuser ${ }^{\dagger}$ \\ Centre for European \\ Economic Research (ZEW) \\ Patrick Schulte $\ddagger$ \\ Centre for European \\ Economic Research (ZEW)
}

January 8, 2014

\begin{abstract}
This paper analyzes the relationship between information and communication technology (ICT) and energy demand. We construct a comprehensive cross-country cross-industry panel data set covering 13 years, 10 OECD countries, and 27 industries. Using up to 2889 country-industry observations, we find that: (1) ICT capital is associated with a significant reduction in energy demand. (2) This relationship differs with regard to different types of energy. ICT use is not significantly correlated with electricity demand, but is significantly related to a reduction in non-electric energy demand. That is, ICT use comes with a reduction in total energy demand and an increase in the relative demand for electric over non-electric energy.
\end{abstract}

JEL Classification: O33; O44; Q41; Q43.

Keywords: Technical Change; ICT; energy demand; energy efficiency; energy mix; Green IT; cross-country cross-industry data; environmental policy.

*We thank Irene Bertschek, Steve Bond, Grazia Cecere, Daniel Erdsiek, Nikolas Georgantzis, Thomas Niebel, Marianne Saam, Thomas Triebs and Michael Ward for their valuable comments. We also benefited from discussions with participants of the Mannheim Energy Conference 2013, the IIIrd Munich ICT Conference 2013 and the seminars at ZEW. Also we would like to thank James Binfield and Liana Platon for very helpful research assistance. For the authors' other projects please refer to http://www.zew.de and to http://www.uni-oldenburg.de/fk2/.

$\dagger$ †.O. Box 103443, D-68034 Mannheim. Email: rexhaeuser@zew.de.

${ }^{\ddagger}$ Corresponding author. P.O. Box 103443, D-68034 Mannheim. Email: schulte@zew.de.

${ }^{\S}$ D - 26111 Oldenburg. Email: heinz.welsch@uni-oldenburg.de. 


\section{Introduction}

Over the last 30 years information and communication technology (ICT) has steadily gained importance and has had a tremendous effect on the world we live in. Despite some initial scepticism about its economic impact, there is now overwhelming evidence of its importance for diverse phenomena, including e.g. productivity growth and labor demand.

More recently, ICT has been ascribed a crucial role in enabling green growth (GeSI 2008, 2012, OECD 2010 or Melville 2010). It is seen to be closely related to the rise of the knowledge economy and might thereby facilitate the decoupling of economic activity from energy use (see Hao and van Ark 2013). ICT is assumed to enable energy and resource efficiency improvements in production and consumption processes through the functionalities it offers, e.g. monitoring of system conditions (via sensors), transmission, processing, storage and illustration of data as well as the driving and control of equipment but also through the direct substitution of physical processes for virtual ones. On the other hand, using ICT equipment is always associated with energy consumption.

Whether this direct use effect of ICT (complementarity effect) or the potential energy efficiency enhancing effect of ICT (substitution effect) dominates is an unresolved question on which surprisingly little evidence exists. Providing comprehensive evidence on this question is the aim of this study. More specifically, our first aim is to analyze the direction of ICT's net impact on energy demand. Secondly, we want to understand how ICT affects the relative demand for different types of energy, namely electric and non-electric energy. Both questions are of relevance to the debate on green growth. This debate focuses on mechanisms to decouple economic activity from pollution. This can be achieved by decoupling economic activity from energy consumption, but also by decoupling energy consumption from pollution. Given that electric- and non-electric energy commodities differ with respect to their emission intensity, shifting the relative demand for them would also have an impact on the overall emission intensity.

To answer these two research questions, we construct a cross-country cross-industry panel data set for 10 OECD countries comprising 27 industries which covers the period from 1995 to 2007 and make use of an empirical framework which draws on the established literature on ICT and labor demand. Based on our extensive data set, we are able to perform a more comprehensive and detailed analysis of the ICT-energy relationship than previous studies. We analyze this relationship for a panel of countries, all economic sectors, and different types of energy and ICT, whereas previous studies, e.g. Collard et 
al. (2005) or Bernstein and Madlener (2010), were able to analyze this relationship only for a few selected industries and one type of energy. Using this data set and controlling for relevant determinants of energy demand, namely for energy prices, other factor prices, non-ICT capital, output, country-industry specific time trends, country-industry and time fixed effects as well as for additional control variables such as R\&D expenditures, human capital and trade related variables, we find a significant negative relationship between ICT and energy demand. Regarding electric and non-electric energy demand, we find that ICT is associated with a reduction in the non-electric energy demand whereas it does not have a significant relation to electric energy demand. Thus, ICT comes with a reduction in total energy demand and changes the composition of energy demand by increasing the relative demand for electric energy.

Our analysis and its findings broaden our knowledge of the economic and environmental consequences of ICT. They show that ICT not only has an impact on the demand for labor, as shown by the literature, but also on the demand for energy. Additionally, our findings might be of relevance to the literature studying the technological and nontechnological determinants of energy demand. The results might also inform theoretical and empirical models that aim to explain (future developments of) the relationship between economic activity and the environment.

The rest of the paper is organized as follows. Section 2 reviews and summarizes the related literature. Section 3 describes our data set and presents descriptive evidence. Section 4 introduces the empirical framework and describes the econometric methods used. Section 5 presents the results, including various robustness checks. Section 6 concludes.

\section{Related Literature}

Our study is related to four different lines of research. First, we build on the established literature on the macroeconomic effects of ICT. Therein, a large literature has analyzed the impact of ICT on labor productivity. It shows that ICT was among the main drivers of labor productivity growth during the last two decades (see Jorgenson (2001) and Stiroh (2002) for seminal works or Draca et al. (2006) and Cardona et al. (2013) for reviews of the literature). Typically this literature assumes a Cobb-Douglas production structure with three input factors, namely labor services, ICT capital services and non-ICT capital services. We follow this literature in its definition and measurement of ICT through ICT capital services but extend its approach in two ways. We include energy as a separate 
input factor and allow for a more flexible production structure which deviates from the Cobb-Douglas assumption of a unitary elasticity of substitution between all inputs. This assumption implies that changing the amount of one input factor, say ICT capital, by e.g. one percent results in an identical demand change of all other inputs by $x$ percent. This might not be realistic. One would expect that substitutability differs across factor pairs. For example it is often argued that ICT capital substitutes for low-skilled labor but is a complement to high-skilled labor. This idea inspired a second strand of the macroeconomic ICT literature which is concerned with the relationship between ICT and labor demand. This literature asks whether ICT-related technical change or ICT capital itself increase the demand for skilled labor. To analyze this question a translog variable cost function approach is typically chosen. For seminal works which use industry-level data see e.g. Berman et al. (1994), Autor et al. (1998), Machin and Van Reenen (1998) and for more recent contributions see Chun (2003), O'Mahony et al. (2008) or Michaels et al. (forthcoming). We closely follow this literature in its theoretical and empirical framework in order to examine the impact of ICT on energy demand.

Second, our research is related to the literature aimed at identifying the determinants of energy demand. Most of the earlier work on energy demand followed the seminal work of Berndt and Wood (1975) which concentrated on capital-energy substitution. More recent work additionally concentrates on technical change and related factors driving withinindustry energy demand developments. Using data on the West German production sector, Welsch and Ochsen (2005) attempt to disentangle the effect of factor substitution, technical change and trade on within-industry energy intensity changes. Technical change is found to be energy-saving whereas an increased trade openness tends to be energy-using. Kratena (2007) uses data on 13 (mainly manufacturing) industries in five European countries to analyze the role of different components of technical change in explaining energy demand. His findings suggest that industries can be classified into two groups: those which exhibit embodied technical change and a larger group showing energy-capital complementarity. He does not distinguish between different types of capital assets. In contrast, Sue Wing (2008), aiming to explain the declining US energy intensity, distinguishes between five different types of capital assets, including IT capital. He finds that intra-industry efficiency gains, in contrast to inter-industry structural change, played a more important role in explaining the energy intensity development in the post 1980-period. His econometric results attribute this phenomenon mainly to adjustments 
in quasi-fixed capital inputs and disembodied technical change. Concerning IT he finds on average a slightly negative long-run elasticity of energy intensity with respect to IT capital. Voigt et al. (2013) confirm the finding that mainly intra-industry efficiency gains were driving energy intensity developments in recent years.

Third, our study is closely related to those studies directly concerned with analyzing the relationship between ICT and energy consumption. Takase and Murota (2004) conduct a simulation analysis where they examine the effect of IT investment on energy consumption and CO2 emissions in Japan and the U.S. They distinguish between income and substitution effects. They find the substitution effect to be dominant in Japan, whereas the income effect is dominant in the U.S. Cho et al. (2007) investigate for South Korea the effects of ICT investment on industries' electricity consumption using a logistic growth model and data from 1991 to 2003. Their results suggest that ICT investment reduces electricity consumption in one specific manufacturing sector ('primary metal products'), whereas in the service sector and most of the manufacturing sectors it increases electricity consumption. Erdmann and Hilty (2010) conduct a scenario analysis to explore the macroeconomic impacts of ICT on greenhouse gas emissions. In most of their scenarios, ICT mitigates GHG emissions. Sadorsky (2012) examines the relationship between ICT and electricity consumption in emerging countries. His results, obtained from a dynamic panel data model, show a positive relationship between ICT and electricity consumption when ICT is measured using internet connections, mobile phones or the number of PCs. Collard et al. (2005) use a factor demand model to analyze the relationship between ICT and electricity use in six French service industries for the period 1986 to 1998. They obtain results which indicate that, once controlling for technical progress, prices, and heated areas, electricity intensity increases with 'computers and software' and decreases with the diffusion of 'communication devices'. Applying the same approach, Bernstein and Madlener (2010) analyze the impact of ICT capital on the electricity intensity of five European manufacturing industries (chemical, food, metal, pulp and paper, textile) for eight European countries from 1991 to 2005. Their analysis provides evidence of an electricity-saving effect on production induced by 'communication technologies', whereas the effect of 'computers and software' is not clear-cut; it differs across industries. These last two studies are the most closely related to ours in terms of theme and data used. However, our data set allows us to analyze the relationship between ICT and energy demand in a more comprehensive way. The data allows us to analyze the effects for nearly 
all economic sectors and various types of energy as well as to employ rigorous empirical methods.

A fourth and very recent strand of literature analyzes the relationship between intangible capital and energy use. Intangible capital and ICT are often seen as complements and integral parts of the emerging knowledge economy. Hao and van Ark (2013) analyze the role of intangible capital investment in reducing country- and industry-level energy intensities. Using data on six European countries from 1995 to 2009, they find intangible capital to be negatively correlated with energy intensity. At the industry level they additionally find tangible ICT investment to be negatively related to energy intensity.

\section{Data}

This section describes our database and presents a descriptive analysis of the relationship between ICT use and energy demand.

\subsection{The Database}

We combine four data sets for this study. The EU KLEMS database is the backbone for this study with additional data being added from the recently published World-InputOutput Database (WIOD), the GGDC Productivity Level Database and the IEA Energy Price Database. We introduce each data set and describe the main steps of the construction of our sample. A more detailed description is provided in Appendix B.

ICT data are obtained from the EU KLEMS Database. This data set, which is described in detail by O'Mahony and Timmer (2009) was, among other reasons, constructed to support the analysis of the impact of ICT on productivity. It provides detailed internationally comparable capital input data for several countries, the full set of economic sectors at a two-digit industry classification level (NACE 1.1), and a period from 1970 to 2007. It also provides two types of capital input data, namely capital stocks and capital services. The capital service concept, compared to the capital stock concept, accounts more explicitly for the fact that different types of capital assets' prices are changing due to technical change at different frequencies and rates. Fast technical change and strongly decreasing prices are characteristic for ICT, which makes the capital service concept the appropriate one for analyzing ICT-related research questions. Using the EU KLEMS data set thus allows us to analyze our research question based on a more accurate measure of ICT capital than previous studies were able to. Additionally, it contains detailed infor- 
mation on subsets of total capital. Next to a split into ICT and non-ICT capital, it also provides information on even more disaggregated capital aggregates, e.g. the following components of ICT capital: 'hardware', 'software' and 'communication equipment'. Along with the capital input data, the EU KLEMS database contains detailed information on other inputs, outputs and factor prices. A detailed description of the raw variables taken from this and the other data sources can be found in Table (17).

Since we are interested in analyzing our research question in a cross-country panel setting, it is necessary to transform all monetary units into common units, in our case into real 1997 US dollars. This is achieved by using industry-level purchasing power parities (PPPs) from the GGDC Productivity Level Database. ${ }^{1}$ It contains PPPs for up to 47 different sectoral aggregates from 30 countries for the year 1997. Both the EU KLEMS and the GGDC Productivity Level Database use the same industry classification system (NACE 1.1) and are constructed in a methodologically coherent way which allows their consistent combination.

Data on industrial energy consumption are obtained from the recently published World-Input-Output Database (WIOD). It contains data on international input-output tables, supply-and-use tables as well as socio-economic and environmental accounts for 40 countries, up to 35 industries and a time period of 15 years (1995 - 2009). A detailed description of the contents and the construction of the database can be found in Timmer (2012) and Dietzenbacher et al. (2013). Its environmental accounts, which include data on energy use, were developed, among other reasons, to allow a consistent combination of energy data with national accounts data at a more detailed industry level than was previously possible. Thus, it lends itself perfectly to the purposes of our analysis. WIOD provides two sets of energy use aggregates: 'gross energy use by commodity' and 'emission relevant energy use by commodity'. The latter excludes from the former the non-energy use of energy commodities and the input of energy commodities for transformation. Since we are interested in ICT's potential role in contributing to green growth we decided to use 'emission relevant energy use'. ${ }^{2}$ WIOD allows us to distinguish between an electric and a non-electric energy use aggregate. It also employs the NACE 1.1 industry classification and provides data at a more or less identical industrial aggregation level as the EU KLEMS and GGDC Productivity Level database. Finally, we complement our sample

\footnotetext{
${ }^{1}$ The sources and methods used in the construction of the GGDC Productivity Level Database are described by Inklaar and Timmer (2008).

${ }^{2}$ Using 'gross energy use' does not alter our results in a significant way, especially not with respect to the effects of ICT.
} 
with information on energy prices. We use the IEA's Energy Prices and Taxes database. It provides separate prices for the electricity sector, the industrial sector and households. Since we are concerned with analyzing the relationship between ICT and industrial energy demand we primarily use the industrial sector 'total price in US dollar per tonne of oil equivalent (toe)'. It includes energy taxes. For non-electric energy we construct a price by computing the industry-specific quantity weighted mean of various non-electric energy prices. ${ }^{3}$ For electric energy we make use of the given electricity prices. ${ }^{4}$

In addition to those four databases, for some of our robustness checks we include information on the trade-, skill-, and R\&D-intensity of industries. The trade data we use consists of import and export data and is taken from the international Input-Output tables in the WIOD database. To proxy the skill intensity of industries we use information on the share of high-skilled labor within industries, which is also obtained from the WIOD database. The sectoral R\&D data are taken from the OECD ANBERD (Analytical Business Enterprise Research and Development) database. We use the data on expenditures by main activity denoted in 2005 US dollars.

Based on these data sources we obtain a data set containing information on industry level output, labor input, capital input (disaggregated into different assets), and electric and non-electric energy quantities and prices. A detailed description of the variables finally available is provided in Table (18) of Appendix B. The sample includes up to 13 years (1995 - 2007), 27 industries and 10 countries (AUT, DNK, ESP, FIN, GER, ITA, JPN, NLD, UK and USA), forming a slightly unbalanced panel of 2889 observations. ${ }^{5}$

\subsection{Descriptive Results}

Tables (1) and (2) report some summary statistics for the production data used in our empirical analysis. Table (1) shows the average variable cost shares of labor $\left(S_{L}\right)$, total

\footnotetext{
${ }^{3}$ For a detailed description of the procedure see Appendix B. As an alternative we used the oil price alone as non-electric energy price proxy. This does not change our results in a notable way.

${ }^{4} \mathrm{~A}$ drawback of energy price information is its low variation across industries within a given country. Across industries, within a country, there is only variation due to differences in the weighting, which stem from differences in sectoral energy mixes. However, given that energy markets are typically national in scope, using these prices should be valid.

${ }^{5}$ In fact, information on two more countries, Sweden and Czech Republic as well as for three more industries, 'electricity, gas and water' (NACE E), 'coke, refined petroleum and nuclear fuel' (NACE 23) and 'real estate activities' (NACE 70) is available. Sweden is excluded since only very few observations were available. Czech Republic is excluded since it is the only 'post-communist' country showing quite different economic structures and developments. Industries E and 23 are excluded since both are energy producing sectors and thus have a completely different production structure concerning energy demand than the remaining industries. The real estate sector is excluded since its capital stock consists mainly of residential structures and thereby strongly differs from other sectors economic structure.
} 
energy $\left(S_{E}\right)$, electric energy $\left(S_{E l e c}\right)$ as well as non-electric energy $\left(S_{N E l e c}\right)$. The labor and energy cost shares sum to 1 since variable costs are defined as the sum of labor and energy costs. The electric and non-electric energy cost shares sum to the total energy cost share. $\left(S_{K_{N}}\right)$ and $\left(S_{K_{I C T}}\right)$ represent the ratio of non-ICT and ICT capital costs to variable costs. The average share of energy in variable costs at the industry level is about $10 \%$.

Table 1: Average Cost Shares, 1995 - 2007

\begin{tabular}{lccccc}
\hline \hline & $\mathrm{N}$ & Mean & SD & Min & Max \\
\hline$S_{L}$ & 3240 & 0.908 & 0.10 & 0.11 & 1.00 \\
$S_{E}$ & 3240 & 0.092 & 0.10 & 0.00 & 0.89 \\
$S_{\text {Elec }}$ & 3240 & 0.038 & 0.04 & 0.00 & 0.42 \\
$S_{N \text { Elec }}$ & 3240 & 0.054 & 0.09 & 0.00 & 0.87 \\
$S_{K_{N}}$ & 3240 & 0.367 & 0.40 & 0.00 & 5.29 \\
$S_{K_{I C T}}$ & 3240 & 0.060 & 0.09 & 0.00 & 1.02 \\
\hline \hline
\end{tabular}

Subscripts refer to labor, energy, electricity, non-electric energy, non-ICT capital and ICT capital respectively.

Labor accounts for the remaining, much larger, share which equals around 90\%. ICT and non-ICT capital together have about half the size of the labor cost share. Splitting total energy into electric and non-electric energy we obtain average shares of $4 \%$ for electric energy and $5 \%$ for non-electric energy.

The key issue addressed in this article is whether within industries the decreasing energy demand per unit of output and the increasing share of electricity in total energy demand can be explained in part by the growing use of ICT. Table (2) reports average annual changes (multiplied by 100) for the variables of interest. ${ }^{6}$ It shows that both labor and energy use were increasing in absolute terms, but were decreasing relative to output. That is, labor productivity and energy efficiency on average increased. Energy efficiency increased by around $1.4 \%$ per year, whereas labor productivity increased by $1.75 \%$ annually. Concerning the composition of the energy mix the data show that there was almost no increase in non-electric energy use. It only increased by $0.1 \%$ per year. In contrast, the consumption of electric energy on average increased by $1.7 \%$ per year. Thus, the composition of energy consumption indeed changed towards relatively more electric energy use. At the same time, the amount of ICT capital services used increased at a

\footnotetext{
${ }^{6}$ It also illustrates a drawback of the WIOD and IEA energy data, their unbalancedness, which is common to all internally comparable industry-level energy data sources. Breaks in time series of single energy sources result in implausibly high growth rates in some years. However, we assume that these breaks are uncorrelated to the use of ICT capital and should thereby not systematically influence our results. We checked the robustness of our results to the presence of outliers and found our results confirmed.
} 
Table 2: $100 \times$ Average Annual Change, 1995 - 2007

\begin{tabular}{lccccc}
\hline \hline & $\mathrm{N}$ & Mean & $\mathrm{SD}$ & Min & Max \\
\hline Cost shares & & & & & \\
$S_{L}$ & 2889 & -0.125 & 1.67 & -16.05 & 13.68 \\
$S_{E}$ & 2889 & 0.125 & 1.67 & -13.68 & 16.05 \\
$S_{\text {Elec }}$ & 2889 & -0.003 & 0.75 & -5.47 & 6.80 \\
$S_{N E l e c}$ & 2889 & 0.128 & 1.44 & -13.61 & 16.52 \\
Flexible factor quantities & & & & & \\
$\ln L$ & 2889 & 0.364 & 3.90 & -24.26 & 14.72 \\
$\ln E$ & 2889 & 0.710 & 12.04 & -111.24 & 95.09 \\
$\ln$ Elec & 2889 & 1.730 & 13.72 & -245.07 & 83.17 \\
$\ln N$ Elec & 2889 & 0.103 & 16.07 & -174.80 & 134.55 \\
Flexible factor prices & & & & & \\
$\ln P_{L}$ & 2889 & 1.302 & 5.74 & -50.93 & 40.92 \\
$\ln P_{E}$ & 2889 & 2.034 & 12.46 & -65.12 & 81.13 \\
$\ln P_{\text {Elec }}$ & 2889 & -0.502 & 13.23 & -58.19 & 42.50 \\
$\ln P_{N \text { Elec }}$ & 2889 & 3.437 & 15.62 & -88.84 & 126.94 \\
Fixed input and output quantities & & & & & \\
$\ln K_{N}$ & 2889 & 1.753 & 3.66 & -42.72 & 26.15 \\
$\ln K_{\text {ICT }}$ & 2889 & 11.875 & 9.49 & -20.01 & 70.77 \\
$\ln Y$ & 2889 & 2.115 & 5.22 & -36.58 & 34.67 \\
Flexible factor intensities & & & & & \\
$\ln (L / Y)$ & 2889 & -1.751 & 5.23 & -30.79 & 40.97 \\
$\ln (E / Y)$ & 2889 & -1.405 & 12.37 & -113.94 & 87.15 \\
\hline \hline
\end{tabular}

very high rate. It increased by around $12 \%$ per year, whereas non-ICT capital grew at a modest $1.7 \%$ annually. Since output itself was growing at $2.1 \%$ per year, non-ICT capital was not only growing at a slower rate than ICT capital: its intensity in output even decreased during this period, whereas that of ICT capital increased considerably. This implies that there has been substitution towards ICT capital and away from non-ICT capital. Thus, the data show that a strongly increasing use of ICT is accompanied by a decreasing use of energy per unit of output and an increasing share of electricity in the energy mix during this period.

Tables (1) and (2) provide mean values averaged over all industries, countries and years. Figure (1) illustrates differences across industries. The upper plot shows the relationship between the industry-specific average growth rate of energy intensity and the industry-specific average ICT capital intensity. There are large differences in both variables across industries. Some industries did not decrease their energy intensity (e.g. the 'construction industry' (NACE F), the 'mining industry' (NACE C) or the 'wood industry' (NACE 20)), whereas other industries saw a fall of about $4 \%$ annually ('post and telecommunication' (NACE 64) or 'electrical or optical equipment' (NACE 30t33)). The average ICT capital intensity also differs strongly across industries. The 'post and 
Figure 1: Sectoral ICT Capital Intensity and Changes in Energy Use
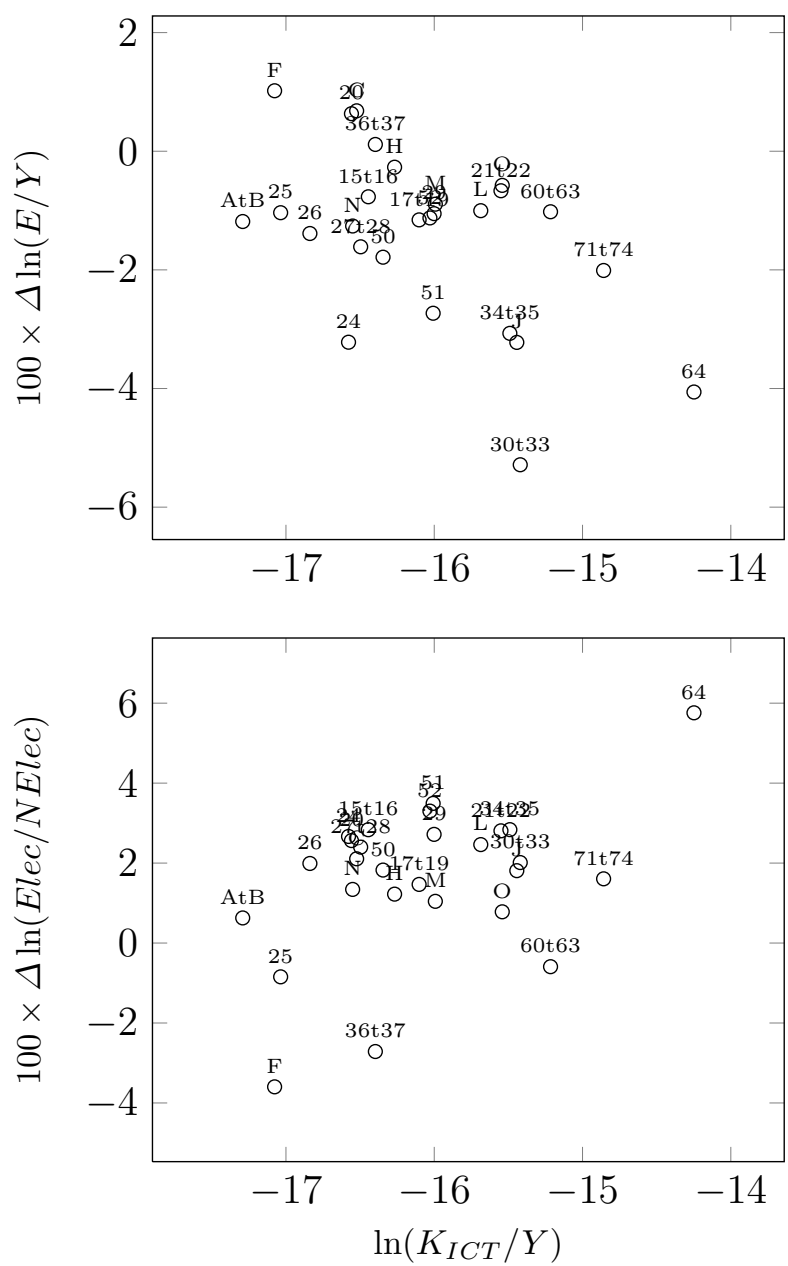

Notes: $\ln \left(K_{I C T} / Y\right)$ refers to the industry-specific average log level of ICT capital service per unit of output. Output equals real value added plus intermediate energy expenditures. $\Delta \ln (E / Y)$ is the industry-specific average annual log change in energy use per unit of output. $\Delta \ln ($ Elec/NElec $)$ is the industry-specific average annual log change in the ratio of electric over non-electric energy use. The labels indicate industries denoted by their NACE 1.1 classification code.

telecommunication' (NACE 64) as well as the 'renting of machinery and equipment and other business activities' (NACE 71t74) industries show a very high ICT capital intensity, whereas the 'agricultural' (NACE AtB) and the 'construction' (NACE F) sectors have a very low ICT capital intensity. There seems to be a negative relationship between these two variables. That is, on average a higher ICT intensity comes with a stronger e decrease in energy intensity. The lower graph shows the relationship between industry specific average growth rates of the ratio of electric over non-electric energy use, and ICT capital intensity. Most industries show a positive average growth rate of this ratio. Two outliers exist, the 'construction' industry (NACE F) and the 'manufacturing of furniture and recycling' industry (NACE 36t37), which show a decreasing share of electric energy consumption. 


\section{Empirical Framework}

\subsection{Model Specification}

To study the relationship between ICT and energy demand, we use a standard restricted variable cost function approach with capital as a quasi-fixed factor (Brown and Christensen 1981). ${ }^{7}$ Assuming that firms minimize their variable costs given output, the ICT and non-ICT capital, and the state of technology, the restricted variable cost function is defined as

$$
V C=f\left(P_{E}, P_{L}, K_{I C T}, K_{N}, Y, t\right)
$$

where $V C$ is variable cost, that is $V C=P_{E} E+P_{L} L . P_{E}$ and $P_{L}$ are energy and labor prices. $E$ and $L$ are energy and labor input quantities. $K_{I C T}$ are ICT capital services, whereas $K_{N}$ are non-ICT capital services. $Y$ is real output, and $t$ is time and represents disembodied technical change.

Assuming a translog cost function and applying Shephard's lemma, we can derive the labor and energy cost share equations. Applying homogeneity of degree one in input prices, we can write the energy price as a relative factor price. The sum of the two cost share equations must equal unity, so only one share equation can be estimated independently. The energy cost share equation is then given by:

$$
S_{E}=\beta_{E}+\beta_{E E} \ln \left(\frac{P_{E}}{P_{L}}\right)+\beta_{K_{I C T}} \ln \left(\frac{K_{I C T}}{Y}\right)+\beta_{K_{N}} \ln \left(\frac{K_{N}}{Y}\right)+\beta_{Y} \ln Y+\delta t,
$$

where $S_{E}=\frac{P_{E} E}{V C}$ is the energy cost share. Capital is decomposed into ICT $\left(K_{I C T}\right)$ and non-ICT capital $\left(K_{N}\right)$. In an additional step, ICT capital will be split into 'computing equipment' $\left(K_{C O M P}\right)$ and 'communication equipment' $\left(K_{C T}\right)$. The coefficient of interest is $\beta_{K_{I C T}}$. A negative coefficient would indicate ICT capital-energy substitutability. The remaining coefficients can be interpreted as follows: A positive sign for $\beta_{E E}$ indicates an elasticity of substitution between energy and labor less than one. $\beta_{K_{N}}$ captures the relationship between non-ICT capital and energy demand. $\beta_{Y}$ indicates the impact of output on the energy cost share. If it is equal to zero, it would indicate constant returns to scale.

To measure the effect size we use demand elasticities. Following Berndt and Hesse (1986) or Kratena (2007), the elasticity of energy demand with respect to quasi-fixed ICT

\footnotetext{
${ }^{7}$ For studies using this methodology in combination with industry-level data, see e.g. Berman et al. (1994), Autor et al. (1998), Machin and van Reenen (1998), Chun (2003), O'Mahony et al. (2008) and Michaels et al. (forthcoming).
} 
capital is: ${ }^{8}$

$$
\epsilon_{E K_{I C T}}=\frac{\ln E}{\ln K_{I C T}}=\frac{\beta_{K_{I C T}}}{S_{E}}-S_{K_{I C T}}=\frac{\ln (E / Y)}{\ln K_{I C T}}=-\frac{\ln (Y / E)}{\ln K_{I C T}}
$$

where $S_{K_{I C T}}=\frac{P_{K_{I C T}} K_{I C T}}{V C}$, with $P_{K_{I C T}}$ being the ICT capital price. That is, the elasticity of energy demand with respect to ICT capital depends on the obtained ICT coefficient, the energy cost share and $S_{K_{I C T}}$. However, it can be shown (see Appendix C), that a sufficient condition for $\epsilon_{E K_{I C T}}<0$ is given by $\beta_{K_{I C T}}<0$. Thus, a negative ICT capital coefficient implies that an increase in ICT use reduces energy demand. Since we assume output to be constant, it would equally imply a reduction in the respective energy intensity $(E / Y)$ and an increase in the respective energy efficiency $(Y / E)$. Analogously, the elasticity of labor demand or labor productivity with respect to ICT capital can also be derived.

To address our second research question, regarding the impact of ICT on the (relative) demand for electric and non-electric energy, we extend our model by splitting the total energy aggregate into electric and non-electric components. Thus, the model now exhibits three variable inputs: labor (L), electric energy (Elec), and non-electric energy (NElec). Maintaining all other assumptions, the following system of two equations results:

$$
\begin{aligned}
S_{j}=\beta_{j \text { Elec }} \ln \left(\frac{P_{\text {Elec }}}{P_{L}}\right) & +\beta_{j N \text { Elec }} \ln \left(\frac{P_{N \text { Elec }}}{P_{L}}\right) \\
& +\beta_{j K_{I C T}} \ln \left(\frac{K_{I C T}}{Y}\right)+\beta_{j K_{N}} \ln \left(\frac{K_{N}}{Y}\right)+\beta_{j Y} \ln Y+\delta_{j},
\end{aligned}
$$

where $j \in\{$ Elec, NElec $\}$ and cross-equation symmetry $\left(\beta_{\text {ElecNElec }}=\beta_{\text {NElecElec }}\right)$ is imposed.

\subsection{Econometric Specification}

In our empirical specification we add a stochastic error term and transform the cost share equations into first-differences to remove country-industry specific time fixed effects. ${ }^{9}$ Equation (2) then becomes:

$$
\begin{aligned}
\Delta S_{E i t}=\beta_{E E} \Delta \ln \left(\frac{P_{E}}{P_{L}}\right)_{i t} & +\beta_{K_{I C T}} \Delta \ln \left(\frac{K_{I C T}}{Y}\right)_{i t} \\
& +\beta_{K_{N}} \Delta \ln \left(\frac{K_{N}}{Y}\right)_{i t}+\beta_{Y} \Delta \ln Y_{i t}+\delta_{i}+e_{i t},
\end{aligned}
$$

\footnotetext{
${ }^{8}$ For a detailed derivation of this elasticity see Appendix C.

${ }^{9}$ Additionally, estimation in first differences reduces the risk of running into spurious regression problems and eliminates potential biases from the usage of purchasing power parities which is known to be prone to measurement error. Running our estimations in levels instead of in first-differences does not change the results very much.
} 
with $e_{i t}=\lambda_{t}+\Delta u_{i t}$, where $\Delta u_{i t}$ is the first-differenced stochastic error term of countryindustry combination $i$ in year $t$. We allow for year specific effects $\lambda_{t}$, and control for country-industry specific unobserved heterogeneity $\delta_{i}$ in the equation in first-differences. The $\delta_{i}$ control for country-industry specific average growth rates. In terms of our theoretical framework, they represent country-industry specific rates of disembodied technical change. Allowing for those three types of unobserved heterogeneity, country-industry time fixed and year fixed effects as well as country-industry specific growth rates is necessary, given that energy efficiency levels and developments across countries and industries differ strongly and cannot be fully explained by the available observables. It is worth making three more remarks concerning this specification. First, in contrast to several studies on the relationship between ICT and labor demand, we do not abstain from including the relative factor (energy) price. This is because we believe that the potential endogeneity problem described in those studies concerning this variable is not relevant in our case, given that energy prices are much more exogeneous than industry- and skill-level specific wages. ${ }^{10}$ Second, from an econometric point of view, in a cross-country cross-industry setting it is necessary to allow not only for the arbitrary correlation of the error terms within a country-industry combination but also for correlation of the error terms across industries within a country. Such correlation should be expected since industries within a country are typically exposed to common shocks. We therefore allow for clustering of observations at the country level. Third, smaller industries might be measured less accurately. To avoid this potential source of heteroscedasticity, we follow the literature and weight these regressions by country-industry specific averages of hours worked of persons engaged.

In the case of total energy, we estimate the cost share equation as defined in equation (5) using the Least Squares Dummy Variable estimator (LSDV). When energy is disaggregated, we have two equations, which we estimate as a system of equations using the iterated Seemingly Unrelated Regressions estimator (ISUR). This allows us to impose cross-equation constraints and exploit cross-equation correlation. ${ }^{11}$

\footnotetext{
${ }^{10}$ Excluding the price variable and replacing it by country-year dummies does not change our results much. Results are available upon request.

${ }^{11}$ As an alternative, we estimate both equations separately using the LSDV estimator in an analogous way as in the case of total energy. The results are very similar to those found with the system estimation approach. Results are available upon request.
} 


\section{Results}

\subsection{Main Results}

Table (3) reports our baseline results concerning the effect of ICT on total energy demand. The baseline sample includes all countries, industries and years available. Specification (1) uses the pooled OLS estimator, where we only include year fixed effects and the variables of interest: changes in relative energy prices, changes in ICT and non-ICT capital intensities and changes in output. We find a significant negative coefficient for both ICT and non-ICT capital. However, including country and industry dummies, as in specification (2), the non-ICT coefficient becomes insignificant, whereas the ICT coefficient remains negative and significant. In our preferred specification, specification (3), we control for country-industry combination specific fixed effects and year fixed effects and still find a highly significant negative ICT coefficient, whereas the non-ICT capital coefficient is again insignificant. The coefficient on the relative price of energy has a positive significant sign. It implies an elasticity of substitution between energy and labor of less than one. The output coefficient is also positive and significantly different from zero, indicating the presence of non-constant returns to scale. The coefficient of ICT capital is equal to -0.016. Employing equation (3), it implies an elasticity of energy demand with respect to ICT capital of -0.235 (see Table (5)). That is, a one percent increase in ICT capital reduces energy demand by 0.235 percent. Assuming output to be constant, it also implies an equally sized increase in energy efficiency. To check the credibility of our results, we consider the second variable input factor, labor, whose relationship to ICT capital has been extensively studied in the literature. Our results imply a demand elasticity of -0.043 . That is, a one percent increase in ICT use reduces labor demand by 0.043 percent or, equivalently, increases labor productivity by 0.043 percent. Interestingly, this magnitude coincides precisely with those effects found by the literature analyzing the relationship between ICT use and labor productivity. For example, Stiroh (2005) finds in his metaanalysis of the literature on ICT and productivity a median estimate of the ICT output elasticity of 0.046 . Thus, our results are qualitatively and quantitatively consistent with previous findings concerning ICT's positive effect on labor productivity. More importantly, we are able to show that ICT also increases energy efficiency by reducing energy demand. In doing so, the effect size with respect to energy exceeds that related to labor demand. 
Table 3: Results on ICT and Total Energy Demand

\begin{tabular}{|c|c|c|c|c|c|c|}
\hline & \multicolumn{3}{|c|}{ Baseline Results } & \multirow{2}{*}{$\frac{\text { CRS }}{(4)}$} & \multirow{2}{*}{$\begin{array}{c}\begin{array}{c}\mathrm{ICT} \\
\text { Indicator }\end{array} \\
(5)\end{array}$} & \multirow{2}{*}{$\begin{array}{c}\text { ICT } \\
\text { Split } \\
(6)\end{array}$} \\
\hline & (1) & $(2)$ & $(3)$ & & & \\
\hline \multicolumn{7}{|l|}{$\Delta S_{E}$} \\
\hline$\Delta \ln \left(P_{E} / P_{L}\right)$ & $\begin{array}{c}0.049^{* * *} \\
(9.08)\end{array}$ & $\begin{array}{c}0.048^{* * *} \\
(8.97)\end{array}$ & $\begin{array}{c}0.047^{* * *} \\
(8.62)\end{array}$ & $\begin{array}{c}0.047^{* * *} \\
(8.49)\end{array}$ & $\begin{array}{c}0.047^{* * *} \\
(8.67)\end{array}$ & $\begin{array}{c}0.047^{* * *} \\
(8.70)\end{array}$ \\
\hline$\Delta \ln \left(K_{I C T} / Y\right)$ & $\begin{array}{c}-0.010^{* *} \\
(-3.08)\end{array}$ & $\begin{array}{c}-0.014^{* * *} \\
(-4.96)\end{array}$ & $\begin{array}{c}-0.016^{* * *} \\
(-6.01)\end{array}$ & $\begin{array}{c}-0.013^{* * *} \\
(-3.79)\end{array}$ & & \\
\hline$\Delta \ln \left(K_{N} / Y\right)$ & $\begin{array}{c}-0.019 * * * \\
(-3.95)\end{array}$ & $\begin{array}{l}-0.004 \\
(-0.51)\end{array}$ & $\begin{array}{l}0.009 \\
(1.03)\end{array}$ & $\begin{array}{c}-0.026^{* *} \\
(-3.13)\end{array}$ & & $\begin{array}{c}0.011 \\
(1.34)\end{array}$ \\
\hline$\Delta \ln Y$ & $\begin{array}{l}0.008 \\
(0.95)\end{array}$ & $\begin{array}{c}0.028^{*} \\
(2.23)\end{array}$ & $\begin{array}{c}0.041^{* * *} \\
(3.26)\end{array}$ & & $\begin{array}{c}0.043^{* * *} \\
(3.41)\end{array}$ & $\begin{array}{c}0.041^{* *} \\
(3.11)\end{array}$ \\
\hline$\Delta \ln (K / Y)$ & & & & & $\begin{array}{l}-0.005 \\
(-0.56)\end{array}$ & \\
\hline$\Delta \ln \left(K_{I C T} / K\right)$ & & & & & $\begin{array}{c}-0.018^{* * *} \\
(-5.29)\end{array}$ & \\
\hline$\Delta \ln \left(K_{C O M P} / Y\right)$ & & & & & & $\begin{array}{c}-0.012^{* * *} \\
(-4.20)\end{array}$ \\
\hline$\Delta \ln \left(K_{C T} / Y\right)$ & & & & & & $\begin{array}{c}-0.006^{* *} \\
(-2.96)\end{array}$ \\
\hline Year DVs & Yes & Yes & Yes & Yes & Yes & Yes \\
\hline Country $\times$ Industry & No & No & Yes & Yes & Yes & Yes \\
\hline Country DVs & No & Yes & No & No & No & No \\
\hline Industry DVs & No & Yes & No & No & No & No \\
\hline Observations & 2889 & 2889 & 2889 & 2889 & 2889 & 2889 \\
\hline Adjusted $R^{2}$ & 0.352 & 0.372 & 0.350 & 0.344 & 0.351 & 0.351 \\
\hline
\end{tabular}

Notes: Heteroscedasticity-robust t-values in parentheses, which are corrected for clustering of observations at the country level. ${ }^{* * *}, * *, *$ : Significantly different from 0 at the $1 \%, 5 \%$, and $10 \%$ levels, respectively. The dependent variable is the change in the energy cost share of a country-industry entity for a given year $t$. All regressions are weighted by the country-industry specific average hours worked by persons engaged. All specifications are estimated using the Least Squares Dummy Variable estimator (LSDV).

Specifications (4) to (6) evaluate the robustness of our results with respect to alternative modeling choices. Specification (4) enforces constant returns to scale, that is, it sets the output coefficient to zero. Doing so has no strong impact on the ICT coefficient. It remains negative, significant, and is only slightly reduced in magnitude. Thus, our result does not depend on this assumption. In contrast, the non-ICT capital coefficient becomes negative and significant. However, given that the output coefficient is highly significantly different from zero in all specifications where it is determined by data, from here on we assume non-constant returns to scale. Specification (5) employs an alternative modeling set-up. Instead of splitting total capital into ICT and non-ICT capital, some authors model the impact of ICT by including an ICT intensity indicator in addition to total capital (see e.g. Berman et al. 1994 or O’Mahony et al. 2008). In such cases ICT intensity is interpreted as a technology indicator instead of ICT being a separate input factor. Using this approach, we find the same qualitative result. The ICT indicator shows a significant 
and negative impact, whereas the coefficient of total capital is insignificant. Thus, this specification also indicates an energy demand reducing role of ICT. Specification (6) splits the ICT capital aggregate into subsets to analyze whether the effects found are driven by specific subcomponents. It is split into 'computing equipment' $\left(K_{C O M P}\right)$ and 'communication equipment' $\left(K_{C T}\right) .{ }^{12}$ Both components show a significant negative effect. Thus, in contrast to the previous literature, which analyzed the impact on electricity demand only, we find a negative impact for both types of ICT.

Table (4) contains our baseline results concerning the impact of ICT on the relative demand for electric and non-electric energy. The upper panel presents the estimation results for the effect on electric energy whereas the lower panel contains the results for non-electric energy. Six specifications are considered. In the baseline specification, specification (3), we again control for year and country-industry fixed effects, both types of relative energy prices, the ICT and non-ICT capital intensity and output. In the electricity equation we find an ICT capital coefficient which is slightly positive (equal to 0.01) but insignificant. In fact, in the electricity equation, the ICT capital coefficients are insignificant in all six specifications, indicating that ICT use does not have a significant net effect on electricity demand. Thus, potential innovations embodied in ICT capital which might reduce electricity use might be counterbalanced by the electricity requirements of the equipment itself. For non-ICT capital we also find insignificant results except in the specifications where we either do not control for country-industry specific time trends or where we assume constant returns to scale. Constant returns to scale again are not supported by the data as the output coefficient is significant in most specifications. For the relative energy prices we find significant results. As expected, the relative non-electric energy price shows a negative sign, whereas the electric energy price shows a positive sign, which is in line with a positive cross-price and a negative own-price elasticity.

In contrast to the results concerning electricity demand, those related to non-electric energy use show a significant and robust negative relationship to ICT. In our preferred specification, specification (3), the ICT coefficient estimate is equal to -0.14 , implying a significant elasticity of non-electric energy demand with respect to ICT capital of -0.319 . In specifications (4) and (5) we again evaluate the effect of assuming constant returns to scale or of modeling ICT as an intensity indicator. In both cases the ICT impact remains negative and significant. When splitting ICT into its subcomponents in specification (6),

\footnotetext{
${ }^{12 ،}$ Computing equipment' consists of 'hardware' and 'software'
} 
we find qualitatively similar results to the specifications analyzing the impact on total energy demand. From these results we conclude that the diffusion of ICT is related to a reduction in demand for non-electric energy but has no significant impact on electric energy demand.

\subsection{Robustness Checks}

\subsubsection{Temporal, Regional and Sectoral Heterogeneity}

Among our assumptions the probably most restrictive one is that of homogeneous estimation coefficients across time, regions, and all country-industry entities. Despite allowing for heterogeneity through country-industry specific fixed effects, country-industry specific time trends and year fixed effects, we assume all remaining parameters, which describe the country-industry specific economic structure, to be identical across time, region and industry. In the following, we relax this assumption to varying degrees.

In a first step we split the sample in various ways and re-estimate our baseline specifications. The results of specifications concerned with total energy demand are given in Table (6). The first four specifications exclude specific groups of entities which strongly differ in their economic structure from the remaining industries and may thereby drive our results. First, we exclude four highly ICT-intensive and in parts ICT-producing industries. They are the 'electrical and optical equipments' (NACE 30t33) industry, the 'post and telecommunications' industry (NACE 64), the 'financial intermediations' (NACE J) industry, and the 'renting of machinery and equipment and other business activities' (NACE 71t74) industries. Doing so reduces our number of observations by around 400, but still leads to a highly significant negative ICT coefficient which is even slightly increased in its magnitude. The other coefficients remain stable. Second, we exclude the most energy-intensive industries, which include the 'agricultural' industry (NACE AtB), the 'mining' industry (NACE C), the 'transport' industry (NACE 60t63), and the 'manufacturing of other non-metallic mineral products' industry (NACE 26). Again, the ICT coefficient remains significant, although the effect size is decreased. The same is true for specification (3) where we exclude public sectors (NACE L, M, N, and O). An exception is the non-ICT capital coefficient, which is positive and significant in this specification. In another step we exclude the US and Japan, which are the only non-European countries in our sample and are known to differ in their economic structure especially with 
Table 4: Results on ICT and Electric and Non-Electric Energy Demand

\begin{tabular}{|c|c|c|c|c|c|c|}
\hline & \multicolumn{3}{|c|}{ Baseline Results } & \multirow{2}{*}{$\frac{\text { CRS }}{(4)}$} & \multirow{2}{*}{$\begin{array}{c}\begin{array}{c}\mathrm{ICT} \\
\text { Indicator }\end{array} \\
(5)\end{array}$} & \multirow{2}{*}{$\begin{array}{c}\text { ICT } \\
\text { Split } \\
(6)\end{array}$} \\
\hline & $(1)$ & $(2)$ & $(3)$ & & & \\
\hline \multicolumn{7}{|l|}{$\Delta S_{\text {Elec }}$} \\
\hline$\Delta \ln \left(P_{\text {NElec }} / P_{L}\right)$ & $\begin{array}{c}-0.001^{*} \\
(-1.74)\end{array}$ & $\begin{array}{l}-0.001 \\
(-1.59)\end{array}$ & $\begin{array}{c}-0.001^{*} \\
(-1.93)\end{array}$ & $\begin{array}{c}-0.001^{* *} \\
(-2.07)\end{array}$ & $\begin{array}{c}-0.001^{*} \\
(-1.95)\end{array}$ & $\begin{array}{c}-0.001^{*} \\
(-1.90)\end{array}$ \\
\hline$\Delta \ln \left(P_{\text {Elec }} / P_{L}\right)$ & $\begin{array}{c}0.020^{* * *} \\
(28.55)\end{array}$ & $\begin{array}{c}0.019^{* * *} \\
(26.37)\end{array}$ & $\begin{array}{c}0.019^{* * *} \\
(28.39)\end{array}$ & $\begin{array}{c}0.019^{* * *} \\
(28.42)\end{array}$ & $\begin{array}{c}0.019 * * * \\
(28.40)\end{array}$ & $\begin{array}{c}0.019^{* * *} \\
(28.33)\end{array}$ \\
\hline$\Delta \ln \left(K_{I C T} / Y\right)$ & $\begin{array}{l}0.001 \\
(0.76)\end{array}$ & $\begin{array}{l}-0.001 \\
(-0.86)\end{array}$ & $\begin{array}{c}0.001 \\
(0.90)\end{array}$ & $\begin{array}{c}0.002 \\
(1.28)\end{array}$ & & \\
\hline$\Delta \ln \left(K_{N} / Y\right)$ & $\begin{array}{c}-0.006^{* * *} \\
(-2.63)\end{array}$ & $\begin{array}{c}-0.005^{*} \\
(-1.82)\end{array}$ & $\begin{array}{l}-0.000 \\
(-0.09)\end{array}$ & $\begin{array}{c}-0.006^{* * *} \\
(-2.75)\end{array}$ & & $\begin{array}{l}0.001 \\
(0.25)\end{array}$ \\
\hline$\Delta \ln Y$ & $\begin{array}{l}-0.000 \\
(-0.03)\end{array}$ & $\begin{array}{l}-0.001 \\
(-0.42)\end{array}$ & $\begin{array}{c}0.006^{*} \\
(1.95)\end{array}$ & & $\begin{array}{c}0.008^{* *} \\
(2.57)\end{array}$ & $\begin{array}{c}0.006^{*} \\
(1.92)\end{array}$ \\
\hline$\Delta \ln (K / Y)$ & & & & & $\begin{array}{c}0.002 \\
(0.81)\end{array}$ & \\
\hline$\Delta \ln \left(K_{I C T} / K\right)$ & & & & & $\begin{array}{c}0.001 \\
(0.49)\end{array}$ & \\
\hline$\Delta \ln \left(K_{C O M P} / Y\right)$ & & & & & & $\begin{array}{l}0.001 \\
(0.74)\end{array}$ \\
\hline$\Delta \ln \left(K_{C T} / Y\right)$ & & & & & & $\begin{array}{l}-0.001 \\
(-0.74) \\
\end{array}$ \\
\hline$\Delta S_{N E l e c}$ & & & & & & \\
\hline$\Delta \ln \left(P_{N E l e c} / P_{L}\right)$ & $\begin{array}{c}0.035^{* * *} \\
(30.16)\end{array}$ & $\begin{array}{c}0.035^{* * *} \\
(30.14)\end{array}$ & $\begin{array}{c}0.035^{* * *} \\
(30.59)\end{array}$ & $\begin{array}{c}0.035^{* * *} \\
(30.44)\end{array}$ & $\begin{array}{c}0.035^{* * *} \\
(30.57)\end{array}$ & $\begin{array}{c}0.035^{* * *} \\
(30.29)\end{array}$ \\
\hline$\Delta \ln \left(P_{\text {Elec }} / P_{L}\right)$ & $\begin{array}{c}-0.001^{*} \\
(-1.74)\end{array}$ & $\begin{array}{l}-0.001 \\
(-1.59)\end{array}$ & $\begin{array}{c}-0.001^{*} \\
(-1.93)\end{array}$ & $\begin{array}{c}-0.001^{* *} \\
(-2.07)\end{array}$ & $\begin{array}{c}-0.001^{*} \\
(-1.95)\end{array}$ & $\begin{array}{c}-0.001^{*} \\
(-1.90)\end{array}$ \\
\hline$\Delta \ln \left(K_{I C T} / Y\right)$ & $\begin{array}{c}-0.009 * * * \\
(-4.46)\end{array}$ & $\begin{array}{c}-0.011^{* * *} \\
(-4.45)\end{array}$ & $\begin{array}{c}-0.014^{* * *} \\
(-5.21)\end{array}$ & $\begin{array}{c}-0.011^{* * *} \\
(-4.25)\end{array}$ & & \\
\hline$\Delta \ln \left(K_{N} / Y\right)$ & $\begin{array}{c}-0.014^{* * *} \\
(-2.97)\end{array}$ & $\begin{array}{l}-0.001 \\
(-0.25)\end{array}$ & $\begin{array}{l}0.007 \\
(0.98)\end{array}$ & $\begin{array}{c}-0.024^{* * *} \\
(-5.58)\end{array}$ & & $\begin{array}{c}0.008 \\
(1.13)\end{array}$ \\
\hline$\Delta \ln Y$ & $\begin{array}{c}0.008^{* *} \\
(1.97)\end{array}$ & $\begin{array}{c}0.028^{* * *} \\
(5.16)\end{array}$ & $\begin{array}{c}0.035^{* * *} \\
(5.42)\end{array}$ & & $\begin{array}{c}0.037^{* * *} \\
(6.22)\end{array}$ & $\begin{array}{c}0.036^{* * *} \\
(5.38)\end{array}$ \\
\hline$\Delta \ln (K / Y)$ & & & & & $\begin{array}{l}-0.006 \\
(-1.12)\end{array}$ & \\
\hline$\Delta \ln \left(K_{I C T} / K\right)$ & & & & & $\begin{array}{c}-0.016^{* * *} \\
(-5.09)\end{array}$ & \\
\hline$\Delta \ln \left(K_{C O M P} / Y\right)$ & & & & & & $\begin{array}{c}-0.010^{* * *} \\
(-4.16)\end{array}$ \\
\hline$\Delta \ln \left(K_{C T} / Y\right)$ & & & & & & $\begin{array}{c}-0.005^{* *} \\
(-2.01)\end{array}$ \\
\hline Year DVs & Yes & Yes & Yes & Yes & Yes & Yes \\
\hline Country $\times$ Industry & No & No & Yes & Yes & Yes & Yes \\
\hline Country DVs & No & Yes & No & No & No & No \\
\hline Industry DVs & No & Yes & No & No & No & No \\
\hline Observations & 2889 & 2889 & 2889 & 2889 & 2889 & 2889 \\
\hline$R_{1}^{2}$ & 0.30 & 0.32 & 0.41 & 0.41 & 0.41 & 0.41 \\
\hline$R_{2}^{2}$ & 0.33 & 0.36 & 0.39 & 0.38 & 0.39 & 0.39 \\
\hline
\end{tabular}

Notes: Heteroscedasticity-robust t-values in parentheses, which are corrected for clustering of observations at the country level. ${ }^{* * *}, * *, *$ : Significantly different from 0 at the $1 \%, 5 \%$, and $10 \%$ levels, respectively. The dependent variable is the change in the energy cost share of a country-industry entity for a given year $t$. All regressions are weighted by the country-industry specific average hours worked by persons engaged. All specifications are estimated by using the iterated Seemingly Unrelated Regression (ISUR). 
Table 5: Factor Demand Elasticities

\begin{tabular}{|c|c|c|c|c|}
\hline \multicolumn{2}{|c|}{ Total Energy Model } & \multicolumn{3}{|c|}{ Electric and Non-Electric Energy Model } \\
\hline$\epsilon_{E K_{I C T}}$ & $\epsilon_{L K_{I C T}}$ & $\epsilon_{\text {Elec }} K_{I C T}$ & $\epsilon_{N E l e c K_{I C T}}$ & $\epsilon_{L K_{I C T}}$ \\
\hline$-0.235^{* * *}$ & $-0.043^{* * *}$ & -0.028 & $-0.319 * * *$ & $-0.048 * * *$ \\
\hline
\end{tabular}

respect to energy use patterns. ${ }^{13}$ In doing so we lose around 600 observations. Still, the ICT coefficient remains negative and significant. Another split divides our sample in two time periods, one covering the period 1995 - 2001 and one covering the remaining years. In both periods the ICT coefficient is quasi unchanged, showing the same magnitude at a three digit level. Thus, there does not seem to be a structural break in the relationship between ICT and energy demand between these two periods. In contrast, there is a change of the non-ICT coefficient between the two periods. In the period leading up to 2001 non-ICT capital has a significant negative coefficient whereas afterwards it does not have a significant coefficient. However, unlike the ICT coefficient the sign and the significance of the non-ICT coefficient depends on the year we choose as the breakpoint for the two periods.

The results of the same robustness checks for the energy subaggregate model are given in Table (11) and also confirm our baseline findings. There are two noteworthy changes. In the specification where we exclude the US and Japan, the ICT coefficient describing the impact on electricity is slightly positive (it equals 0.002 ) and significant. In the period past 2001, in the electricity equation the non-ICT coefficient becomes negative. Concerning non-electric energy, the ICT coefficient is again significant and negative in all specifications whereas non-ICT capital is insignificant in all specifications.

In a second set of robustness checks we split our industry sample into two broad sectors, the manufacturing and the service sector. The results we obtain for them can be found in Tables (7) and (12). Table (7) shows the effect of ICT to be negative and significant in the manufacturing sector but to be insignificant in the service sector. However, the result for the service sector is not very robust. If the transport sector is included, the ICT coefficient becomes significant. Differences across sectors are not surprising and in the case of the service sector could reflect the inherently little (non-electric) energy use and the

\footnotetext{
${ }^{13}$ See e.g. Voigt et al. (2013), who show that in these two countries structural change plays a much more prominent role in driving energy efficiency developments than in most other countries.
} 
accompanied limited potential to increase (non-electric) energy efficiency. With respect to electric and non-electric energy demand, we find a similar pattern. ICT capital has no significant coefficient in the electricity equation, whereas it has a significant negative coefficient on non-electric energy in the manufacturing sector. In the service sector we do not find any significant effect.

In a third attempt aimed at relaxing the assumption of homogeneous estimation coefficients we go one step further and estimate our model for each industry separately. We include time fixed effects and country fixed effects. This leaves us with around 100 observations per industry, which is a small number of observations given the complexity of our model (82 degrees of freedom remain per estimation). Thus, the validity of the results obtained with it might be limited. For total energy the results are given in Table (8). We find a significant ICT coefficient in just four industries (NACE 24, H, 60t63 and O). In all four cases we find a negative sign, indicating a negative relationship between ICT and energy demand. Splitting energy up, we also find few significant results, but those we do find again tend to support our previous findings (see Tables (13) and (14)). For electric energy, the ICT coefficient is significant in five industries (NACE 17t19, F, H, $60 t 63$ and L) and negative in only three out of those five cases. For non-electric energy, we find a significant ICT effect in nine industries (NACE 24, F, 60t63, J, 71t74, L, M, N and $\mathrm{O})$ which is negative in eight of those industries. ${ }^{14}$

Overall, we conclude that our baseline findings are robust to various samples and assumptions concerning the degree of homogeneity of economic structures across industries, countries and time.

\subsubsection{Endogeneity Issues}

Up to this point, we assume strict exogeneity of all explanatory variables, that is, we assume that they are uncorrelated with past, future and contemporaneous shocks $u_{i t}$. As Berman et al. (1994) note, due to the fact that planning horizons for new investment are presumably a couple of years, the endogeneity bias caused by simultaneity should not be

\footnotetext{
${ }^{14}$ Another even more flexible approach we employed allows each country-industry combination to have its own technology parameters. This can be achieved by applying various forms of Mean Group estimators developed by Pesaran and Smith (1995) and Pesaran et al. (1999). Unfortunately, their results are only reliable for a relatively large $\mathrm{T}$ per panel entity. Given that $\mathrm{T}$ equals 13 years in our case, this kind of estimator could be biased. We employed the Mean Group estimator (MG) by using the recently introduced xtmg command in Stata (Eberhardt (2012)). We used the robust option and included a time trend in each entity estimation, which proxies the effect of time fixed effects. The results can be obtained upon request. They support our baseline findings, that is, the ICT coefficient remained negative and significant. Most other coefficients, except the price coefficient, were insignificant.
} 
too severe if one uses annual data. Since we use annual data and additionally do not see any reasons why our dependent variable (a cost share) should have a causal impact on the level of ICT use, we discard reverse causality as a source of endogeneity. However, omitted variables and measurement error in the right hand side variables can be expected to cause endogeneity. That is, despite controlling for forms of unobserved omitted variables, namely those ones characterized by time invariant levels or time invariant growth rates, omitted variables still might cause correlation between the error term $u_{i t}$ and ICT. E.g. within-industry structural change, such as replacing 'manufacturing' jobs by 'service' jobs might not be fully covered by those types of fixed effects and could at the same time increase ICT use and decrease the energy cost share. Omitted variable bias aside, measurement error in the right hand side variables might cause endogeneity. In the case of aggregate inputs we always expect some form of measurement error.

To tackle the issue of endogeneity we apply two strategies. In a first approach, we include additional control variables which might proxy for the potentially most serious sources of omitted variable bias. These include information on $R \& D$, the share of high skilled labor in an industry, and trade-related variables.

$\mathrm{R} \& \mathrm{D}$ is often seen as an alternative technology indicator, which is shown to have a significant impact on various economic phenomena. We include it since it may also have an impact on firms' or industries' energy efficiency and is assumed to be correlated with the ICT intensity of industries. However, including the R\&D data taken from the OECD ANBERD database comes at the cost of losing several observations, since this variable is not covered too well. Thus, in Table (9), where we present the results obtained by including additional control variables, we first show the results obtained with the sample of observations for which we have $R \& D$ data available, but without including the $R \& D$ variable itself. This allows us to distinguish the effect of using this specific sample from the effect of R\&D itself. Specification (1) shows that this reduces our number of observations to around 1418, but does not change our results qualitatively. Specification (2) includes $\mathrm{R} \& \mathrm{D}$, in the form of a logarithmic $\mathrm{R} \& \mathrm{D}$ intensity. It does not have a notable effect on the other coefficients. The R\&D coefficient is negative but insignificant. This finding is surprising to us and might be interpreted as evidence for a distinct role of ICT which differs from technical change in general, which is often proxied by R\&D.

As argued above, structural change within industries may increase the share of 'service' like production relative to 'manufacturing' like activities and might thereby increase the 
use of ICT and reduce energy demand. To proxy for this potential phenomenon, we include the change in the share of total hours worked by high-skilled labor. Here one would expect an increasing share of high-skilled labor to come with a decreasing energy cost share. Actually, in specification (4) we find a negative but insignificant coefficient for the change in high-skilled labor. It, however, becomes significant if we exclude the country-industry fixed effects from our regression. This might indicate that this form of omitted variable is already controlled for by the fixed effects we include.

Trade-related variables are included since trade is also often found to have an impact on (industrial) factor demands and especially on energy demand. ${ }^{15}$ At the same time, it is often shown that firms participating in trade tend to be more ICT intensive. Including information on imports and exports reduces our sample to 2241 observations. Again, this reduction has no notable impact on our results. Specification (5) includes the change in the log import intensity. It has no significant impact. Including the change in log export intensity in specification (6) has a negative and significant effect. However, both the import and export effects are small in size and affect neither the ICT capital coefficient nor the other coefficients in a notable way. Including the change in trade openness in specification (7), which is the log of the sum of imports and exports divided by value added also does not change our results very much. Going one step further and including all three types of controls, $\mathrm{R} \& \mathrm{D}$, the change in the high-skilled labor share and trade openness in one specification shows a negative significant effect of trade openness, whereas the other two coefficients remain insignificant. Again, dropping the country-industry fixed effects results in the skilled labor share also becoming significant.

With respect to the results related to electric and non-electric energy we find similar patterns (see Table (15)). In the equation describing the impact on electric energy demand none of the control variables added shows any significant impact. In contrast, all three types of control variables show significant effects on non-electric energy demand without changing the size or significance of the ICT coefficients. To conclude, including countryindustry specific fixed effects and growth rates seems to cover several potential sources of omitted variable bias and omitting those three specific types of variables does not invalidate our main results.

In a second approach chosen to address the potential endogeneity of ICT we apply IV

\footnotetext{
${ }^{15}$ See e.g. Welsch and Ochsen (2005) on the relationship between trade and energy demand. Also, within the carbon leakage debate it is discussed whether firms relocate emission or energy intensive activities to countries with lower energy prices or lower environmental regulatory standards and thereby become statistically less polluting or less energy intensive.
} 
methods. We make use of the Difference-GMM estimator developed by Arellano and Bond (1991), which uses lagged levels as instruments. ${ }^{16}$ In doing so we follow e.g. Dobbelaere and Mairesse (2013) and apply the method to both a static and a dynamic representation of our model. It ensures the robustness of our results towards the presence of different forms of serial correlation. E.g. transforming our model into a simple autoregressive distributed lag model (ARDL) we can allow the error term $u_{i t}$ of equation (5) to have a potentially autoregressive form, that is $u_{i t}=\rho u_{i t-1}+\epsilon_{i t}$. As instruments, we only include values lagged three periods and more, since our model is defined in first-differences which would render observations lagged less than three periods invalid in the presence of endogeneity. Allowing for measurement error additionally requires excluding observations lagged three periods. The results we obtain are given in Table (10). In two out of four specifications we find significant results for the ICT coefficient. In all specifications the ICT coefficients are negative. Our preferred specification, specification (4), assumes the least restrictive assumptions by allowing for autoregressive error terms and measurement error. It shows a negative and significant ICT coefficient. Both the energy price and the output coefficient show the same sign as in our baseline specification: a positive coefficient. The non-ICT coefficient remains positive but in contrast to our baseline findings becomes significant. Even though these results seem to corroborate our baseline findings one has to keep in mind that using the Difference-GMM estimator requires several assumptions which may not be fulfilled, e.g. in our case the Hansen test for the joint validity of the instruments rejects their validity in all four specifications. The results describing the relationship to electric and non-electric energy also seem to corroborate our main findings. ICT does not display a significant association with electric energy demand, but a negative significant impact on the non-electric energy cost share. Both findings hold for all four specifications. Again, in most of the specifications the Hansen test rejects the validity of the instruments. Only the two dynamic specifications describing the effect on nonelectric energy exhibit Hansen tests which do not reject the validity of the instruments. This underlines our conclusion that ICT is negatively related to energy demand through its association with a reduced non-electric energy demand.

To conclude, using several methods to tackle the potential endogeneity of ICT, in most specifications the coefficient describing the role of ICT remains negative and significant.

\footnotetext{
${ }^{16}$ We are aware that the Difference-GMM estimator might be inefficient but still decided against using the more efficient System-GMM estimator developed by Arellano and Bover (1995) and Blundell and Bond (1998), since the System-GMM estimator requires additional assumptions on the initial conditions which we think are to restrictive in the case of our application.
} 
Nonetheless, following Micheals et al. (forthcoming) in their interpretation of their results, we emphasize that using such methods and instruments does not necessarily uncover the causal effect of ICT. Thus, we interpret our results as conditional correlations showing a strong and negative relationship between ICT and energy demand.

\section{Conclusion}

In this article we analyze the relationship between ICT and energy demand by using a panel data set for 10 OECD countries, 27 industries, and 13 years. Estimating variable cost share equations derived from a translog variable cost function approach, we obtain two main findings. First, controlling for the relevant determinants of energy demand, we find a significant negative relationship between ICT and energy demand. That is, we find strong evidence for ICT capital-energy substitutability. Secondly, we analyze the relationship between ICT and the relative demand for two types of energy, electric and non-electric energy. We show that ICT use has no significant association with electric energy demand, whereas non-electric energy demand decreases significantly with increasing ICT use. That is, our results are in line with the hypothesis that the diffusion of ICT comes with an increase in the relative demand for electric energy. Our results survive several robustness checks which allow for various forms of heterogeneity among panel entities, tackle the issue of endogeneity and control for several potentially omitted variables such as R\&D efforts, human capital intensities and the trade openness of industries.

Although our study is an important step in analyzing the relationship between ICT and energy demand we are aware of several limitations. To identify a truly causal effect of ICT on energy demand, additional evidence, making use of alternative instrumental variables, would be necessary. Future research should also strive for firm-level evidence on this relationship. In addition, extending the research question towards the consumer side could prove highly insightful, given that a large share of ICT consumption is done privately. 


\section{References}

Arellano, M., And S. Bond (1991): "Some Tests of Specification for Panel Data: Monte Carlo Evidence and an Application to Employment Equations," The Review of Economic Studies, 58(2), 277-297.

Arellano, M., And O. Bover (1995): "Another Look at the Instrumental Variable Estimation of Error-Components Models," Journal of Econometrics, 68(1), 29-51.

Autor, D., L. Katz, and A. Krueger (1998): "Computing Inequality: Have Computers Changed the Labor Market?," The Quarterly Journal of Economics, 113(4), 1169-1213.

Berman, E., J. Bound, And Z. Griliches (1994): "Changes in the Demand for Skilled Labor within US Manufacturing: Evidence from the Annual Survey of Manufactures," The Quarterly Journal of Economics, 109(2), 367-397.

Berndt, E. R., And D. M. Hesse (1986): "Measuring and Assessing Capacity Utilization in the Manufacturing Sectors of Nine OECD Countries," European Economic Review, 30(5), 961-989.

Berndt, E. R., And D. Wood (1975): "Technology, Prices, and the Derived Demand for Energy," The Review of Economics and Statistics, 57(3), 259-268.

Bernstein, R., And R. Madlener (2010): "Impact of Disaggregated ICT Capital on Electricity Intensity in European Manufacturing," Applied Economics Letters, 17(17), 1691-1695.

Blundell, R., And S. Bond (1998): "Initial Conditions and Moment Restrictions in Dynamic Panel Data Models," Journal of Econometrics, 87(1), 115-143.

Brown, R., and L. Christensen (1981): "Estimating Elasticities of Substitution in a Model of Partial Static Equilibrium: An Application to US Agriculture 1947 to 1974," in Modeling and Measuring Natural Resource Substitution.

Cardona, M., T. Kretschmer, and T. Strobel (2013): "ICT and Productivity: Conclusions from the Empirical Literature," Information Economics and Policy, 25(3), $109-125$. 
Cho, Y., J. LeE, And T.-Y. Kim (2007): "The Impact of ICT Investment and Energy Price on Industrial Electricity Demand: Dynamic Growth Model Approach," Energy Policy, 35(9), 4730-4738.

Chun, H. (2003): "Information Technology and the Demand for Educated Workers: Disentangling the Impacts of Adoption Versus Use," The Review of Economics and Statistics, 85(1), 1-8.

Collard, F., P. Fève, And F. Portier (2005): "Electricity Consumption and ICT in the French Service Sector," Energy Economics, 27(3), 541-550.

Dietzenbacher, E., B. Los, R. Stehrer, M. P. Timmer, and G. De Vries (2013): "The Construction of World Input-Output Tables in the WIOD Project," Economic Systems Research, 25(1), 71-98.

Dobbelaere, S., And J. Mairesse (2013): "Panel Data Estimates of the Production Function and Product and Labor Market Imperfections," Journal of Applied Econometrics, 28(1), 1-46.

Draca, M., R. Sadun, and J. Van Reenen (2006): "Productivity and ICT: A Review of the Evidence," Discussion paper.

Eberhardt, M. (2012): "Estimating Panel Time-Series Models with Heterogeneous Slopes," The Stata Journal, 12(1), 61-71.

Erdmann, L., And L. M. Hilty (2010): "Scenario Analysis - Exploring the Macroeconomic Impacts of Information and Communication Technologies on Greenhouse Gas Emissions," Journal of Industrial Ecology, 14(5), 826-843.

Foster, N., R. Stehrer, And G. J. De VRIEs (2013): "Offshoring and the Skill Structure of Labour Demand," Review of World Economics, 149(4), 1-32.

GESI (2008): "SMART 2020: Enabling the Low Carbon Economy in the Information Age," Discussion paper, A Report by The Climate Group on Behalf of the Global e-Sustainability Initiative.

(2012): "SMARTer 2020: The Role of ICT in Driving a Sustainable Future," Discussion paper, A Report by The Climate Group on Behalf of the Global e-Sustainability Initiative. 
HaO, Janet, X., And B. VAn ArK (2013): "Intangible Investment and the Intensity of Energy Use," Discussion paper.

Hijzen, A., H. Görg, And R. C. Hine (2005): "International Outsourcing and the Skill Structure of Labour Demand in the United Kingdom," The Economic Journal, 115(506), 860-878.

InklaAR, R., And M. P. Timmer (2007): "International Comparisons of Industry Output, Inputs and Productivity Levels: Methodology and New Results," Economic Systems Research, 19(3), 343-363.

(2008): "GGDC Productivity Level Database: International Comparisons of Output, Inputs and Productivity at the Industry Level," GGDC Research Memorandum.

InklaAR, R., And M. P. Timmer (2009): "Productivity Convergence across Industries and Countries: the Importance of Theory-Based Measurement," Macroeconomic Dynamics, 13(S2), 218-240.

Jorgenson, D. W. (2001): "Information Technology and the US Economy," The American Economic Review, 91(1), 1-32.

Kratena, K. (2007): "Technical Change, Investment and Energy Intensity," Economic Systems Research, 19(3), 295-314.

Machin, S., And J. Van Reenen (1998): "Technology and Changes in Skill Structure: Evidence from Seven OECD Countries," The Quarterly Journal of Economics, 113(4), $1215-1244$.

Melville, N. P. (2010): "Information Systems Innovation for Environmental Sustainability," MIS Quarterly, 34(1), 1-21.

Michaels, G., A. Natraj, and J. Van Reenen (forthcoming): "Has ICT Polarized Skill Demand? Evidence from Eleven Countries over 25 Years," The Review of Economics and Statistics.

OECD (2010): "Greener and Smarter: ICTs, the Environment and Climate Change," Discussion paper, OECD Publishing. 
O’Mahony, M., C. Robinson, and M. Vecchi (2008): "The Impact of ICT on the Demand for Skilled Labour: a Cross-Country Comparison," The Journal of Labor Economics, 15(6), 1435-1450.

O’Mahony, M., and M. P. Timmer (2009): "Output, Input and Productivity Measures at the Industry Level: The EU KLEMS Database," The Economic Journal, 119(538), $374-403$.

Pesaran, M. H., Y. Shin, and R. P. Smith (1999): "Pooled Mean Group Estimation of Dynamic Heterogeneous Panels," Journal of the American Statistical Association, 94(446), 621-634.

Pesaran, M. H., and R. Smith (1995): "Estimating Long-Run Relationships from Dynamic Heterogeneous Panels," The Journal of Econometrics, 68(1), 79-113.

SAdorsky, P. (2012): "Information Communication Technology and Electricity Consumption in Emerging Economies," Energy Policy, 43, 130-136.

Serletis, A., G. Timilsina, And O. Vasetsky (2011): "International evidence on aggregate short-run and long-run interfuel substitution," Energy Economics, 33(2), 209216.

Stiroh, K. J. (2002): "Information Technology and the US Productivity Revival: What Do the Industry Data Say?," The American Economic Review, 92(5), 1559-1576.

(2005): "Reassessing the Impact of IT in the Production Function: a MetaAnalysis and Sensitivity Tests," Annales d'Economie et de Statistique, 78, 529-561.

Sue Wing, I. (2008): "Explaining the Declining Energy Intensity of the US Economy," Resource and Energy Economics, 30(1), 21-49.

Takase, K., And Y. Murota (2004): "The Impact of IT Investment on Energy: Japan and US Comparison in 2010," Energy Policy, 32(11), 1291-1301.

Timmer, M. P. (2012): "The World Input-Output Database (WIOD): Contents, Sources and Methods," WIOD discussion paper nr. 10, available at: http://www.wiod.org/.

Voigt, S., E. De Cian, M. Schymura, and E. Verdolini (2014): "Energy Intensity Developments in 40 Major Economies: Structural Change or Technology Improvement?," Energy Economics, 41, 47-62. 
Welsch, H., And C. Ochsen (2005): "The Determinants of Aggregate Energy Use in West Germany: Factor Substitution, Technological Change, and Trade," Energy Economics, 27(1), 93-111. 


\section{Appendix}

\subsection{Appendix A: Tables}

\section{Total Energy Tables}

Table 6: Robustness Checks I - Total Energy - Sample Splits

\begin{tabular}{|c|c|c|c|c|c|c|}
\hline & $\begin{array}{l}\text { W/o ICT- } \\
\text { Intensive } \\
\text { Industries }\end{array}$ & $\begin{array}{l}\text { W/o Energy- } \\
\text { Intensive } \\
\text { Industries }\end{array}$ & $\begin{array}{c}\text { W/o Public } \\
\text { Services }\end{array}$ & $\begin{array}{l}\text { W/o US, } \\
\text { JPN }\end{array}$ & $\begin{array}{c}\text { Pre } \\
2002\end{array}$ & $\begin{array}{l}\text { Past } \\
2001\end{array}$ \\
\hline & (1) & $(2)$ & $(3)$ & (4) & (5) & (6) \\
\hline$\Delta \ln \left(P_{E} / P_{L}\right)$ & $\begin{array}{c}0.052^{* * * *} \\
(9.01)\end{array}$ & $\begin{array}{c}0.037^{* * *} \\
(6.54)\end{array}$ & $\begin{array}{c}0.056^{* * *} \\
(11.56)\end{array}$ & $\begin{array}{c}0.044^{* * *} \\
(5.62)\end{array}$ & $\begin{array}{c}0.038^{* * *} \\
(6.99)\end{array}$ & $\begin{array}{c}0.061^{* * *} \\
(6.95)\end{array}$ \\
\hline$\Delta \ln \left(K_{I C T} / Y\right)$ & $\begin{array}{c}-0.019^{* * *} \\
(-6.12)\end{array}$ & $\begin{array}{c}-0.008^{* *} \\
(-2.34)\end{array}$ & $\begin{array}{c}-0.017^{* * *} \\
(-5.18)\end{array}$ & $\begin{array}{c}-0.014^{* *} \\
(-2.45)\end{array}$ & $\begin{array}{c}-0.017^{* *} \\
(-2.69)\end{array}$ & $\begin{array}{c}-0.017^{*} \\
(-2.24)\end{array}$ \\
\hline$\Delta \ln \left(K_{N} / Y\right)$ & $\begin{array}{l}-0.003 \\
(-0.30)\end{array}$ & $\begin{array}{l}0.000 \\
(0.04)\end{array}$ & $\begin{array}{c}0.019^{*} \\
(1.89)\end{array}$ & $\begin{array}{c}0.003 \\
(0.33)\end{array}$ & $\begin{array}{c}-0.020^{* *} \\
(-2.64)\end{array}$ & $\begin{array}{l}0.001 \\
(0.06)\end{array}$ \\
\hline$\Delta \ln Y$ & $\begin{array}{c}0.043^{* *} \\
(2.58)\end{array}$ & $\begin{array}{l}0.012 \\
(1.30)\end{array}$ & $\begin{array}{c}0.054^{* * *} \\
(4.57)\end{array}$ & $\begin{array}{c}0.071^{*} \\
(2.34)\end{array}$ & $\begin{array}{l}0.010 \\
(0.68)\end{array}$ & $\begin{array}{l}0.027 \\
(0.87)\end{array}$ \\
\hline Year DVs & Yes & Yes & Yes & Yes & Yes & Yes \\
\hline Count $\times$ Ind DVs & Yes & Yes & Yes & Yes & Yes & Yes \\
\hline Observations & 2461 & 2461 & 2461 & 2268 & 1593 & 1296 \\
\hline Adjusted $R^{2}$ & 0.376 & 0.338 & 0.381 & 0.344 & 0.271 & 0.429 \\
\hline
\end{tabular}

Notes: Heteroscedasticity-robust t-values in parentheses, which are corrected for clustering of observations at the country level. $* * *, * *, *$ : Significantly different from 0 at the $1 \%, 5 \%$, and $10 \%$ levels, respectively. The dependent variable is the change in the energy cost share of a country-industry entity for a given year $t$. All regressions are weighted by the country-industry specific average hours worked by persons engaged. All specifications are estimated using the Least Squares Dummy Variable estimator (LSDV). ICT-intensive industries include NACE 30t33, 64, J, and 71t74.

Energy-intensive include NACE AtB, C, 60t63, and 26. Public services include NACE L, M, N, and O.

Table 7: Robustness Checks II - Total Energy - Sectoral Split

\begin{tabular}{|c|c|c|c|c|c|c|}
\hline & \multicolumn{3}{|c|}{ Manufacturing Sector } & \multicolumn{3}{|c|}{ Service Sector } \\
\hline & (1) & $(2)$ & $(3)$ & (4) & $(5)$ & (6) \\
\hline$\Delta \ln \left(P_{E} / P_{L}\right)$ & $\begin{array}{c}0.080^{* * *} \\
(7.45)\end{array}$ & $\begin{array}{c}0.080^{* * *} \\
(7.08)\end{array}$ & $\begin{array}{c}0.080^{* * *} \\
(6.97)\end{array}$ & $\begin{array}{c}0.024^{* * *} \\
(5.90)\end{array}$ & $\begin{array}{c}0.024^{* * *} \\
(5.73)\end{array}$ & $\begin{array}{c}0.024^{* * *} \\
\quad(5.67)\end{array}$ \\
\hline$\Delta \ln \left(K_{I C T} / Y\right)$ & $\begin{array}{c}-0.021^{* *} \\
(-2.32)\end{array}$ & $\begin{array}{c}-0.023^{*} \\
(-2.22)\end{array}$ & $\begin{array}{c}-0.016^{*} \\
(-1.89)\end{array}$ & $\begin{array}{l}-0.004 \\
(-1.39)\end{array}$ & $\begin{array}{l}-0.003 \\
(-1.03)\end{array}$ & $\begin{array}{l}-0.004 \\
(-1.00)\end{array}$ \\
\hline$\Delta \ln \left(K_{N} / Y\right)$ & $\begin{array}{l}0.022 \\
(1.35)\end{array}$ & $\begin{array}{c}0.028 \\
(1.07)\end{array}$ & $\begin{array}{l}-0.014 \\
(-1.33)\end{array}$ & $\begin{array}{l}0.002 \\
(0.32)\end{array}$ & $\begin{array}{l}0.001 \\
(0.19)\end{array}$ & $\begin{array}{c}0.003 \\
(0.67)\end{array}$ \\
\hline$\Delta \ln Y$ & $\begin{array}{l}0.035 \\
(1.81)\end{array}$ & $\begin{array}{l}0.038 \\
(1.43)\end{array}$ & & $\begin{array}{l}-0.005 \\
(-0.83)\end{array}$ & $\begin{array}{l}-0.002 \\
(-0.30)\end{array}$ & \\
\hline Year & Yes & Yes & Yes & Yes & Yes & Yes \\
\hline Country $\times$ Industry & No & Yes & Yes & No & No & No \\
\hline Observations & 1284 & 1284 & 1284 & 1177 & 1177 & 1177 \\
\hline Adjusted $R^{2}$ & 0.496 & 0.473 & 0.471 & 0.519 & 0.504 & 0.505 \\
\hline
\end{tabular}

Notes: Heteroscedasticity-robust t-values in parentheses, which are corrected for clustering of observations at the country level. ***, **, *: Significantly different from 0 at the $1 \%, 5 \%$, and $10 \%$ levels, respectively. The dependent variable is the change in the energy cost share of a country-industry entity for a given year $t$. All regressions are weighted by the country-industry specific average hours worked by persons engaged. All specifications are estimated using the Least Squares Dummy Variable estimator (LSDV). 
Table 8: Robustness Checks III - Total Energy - Industry Specific Estimates

\begin{tabular}{|c|c|c|c|c|c|c|c|c|c|c|c|c|c|c|}
\hline & AtB & $\mathrm{C}$ & $15 \mathrm{t} 16$ & $17 \mathrm{t} 19$ & 20 & $21 \mathrm{t} 22$ & 24 & 25 & 26 & $27 \mathrm{t} 28$ & 29 & $30 \mathrm{t} 33$ & $34 \mathrm{t} 35$ & $36 \mathrm{t} 37$ \\
\hline$\Delta \ln \left(P_{E} / P_{L}\right)$ & $\begin{array}{c}0.067^{* * *} \\
(6.96)\end{array}$ & $\begin{array}{c}0.112^{* * *} \\
(9.75)\end{array}$ & $\begin{array}{c}0.092^{* * *} \\
(7.14)\end{array}$ & $\begin{array}{c}0.083^{* * *} \\
(7.03)\end{array}$ & $\begin{array}{c}0.056^{* * *} \\
(4.95)\end{array}$ & $\begin{array}{c}0.118^{* * *} \\
(10.08)\end{array}$ & $\begin{array}{c}0.192^{* * *} \\
(8.05)\end{array}$ & $\begin{array}{c}0.053^{* *} \\
(2.21)\end{array}$ & $\begin{array}{c}0.164^{* * *} \\
(6.82)\end{array}$ & $\begin{array}{c}0.100^{* * * *} \\
(3.83)\end{array}$ & $\begin{array}{c}0.054^{* * *} \\
(5.34)\end{array}$ & $\begin{array}{c}0.034^{* * *} \\
(3.25)\end{array}$ & $\begin{array}{c}0.040^{* * *} \\
(8.75)\end{array}$ & $\begin{array}{l}0.010 \\
(0.97)\end{array}$ \\
\hline$\Delta \ln \left(K_{I C T} / Y\right)$ & $\begin{array}{l}-0.017 \\
(-1.16)\end{array}$ & $\begin{array}{l}-0.021 \\
(-0.70)\end{array}$ & $\begin{array}{l}-0.024 \\
(-1.06)\end{array}$ & $\begin{array}{l}-0.026 \\
(-1.50)\end{array}$ & $\begin{array}{l}0.002 \\
(0.10)\end{array}$ & $\begin{array}{l}-0.015 \\
(-0.70)\end{array}$ & $\begin{array}{c}-0.130^{* *} \\
(-2.43)\end{array}$ & $\begin{array}{l}-0.018 \\
(-0.32)\end{array}$ & $\begin{array}{l}-0.021 \\
(-0.71)\end{array}$ & $\begin{array}{l}-0.066 \\
(-1.15)\end{array}$ & $\begin{array}{c}0.003 \\
(0.21)\end{array}$ & $\begin{array}{l}0.004 \\
(0.34)\end{array}$ & $\begin{array}{l}-0.002 \\
(-0.15)\end{array}$ & $\begin{array}{l}-0.005 \\
(-0.20)\end{array}$ \\
\hline$\Delta \ln \left(K_{N} / Y\right)$ & $\begin{array}{l}-0.009 \\
(-0.49)\end{array}$ & $\begin{array}{c}-0.311^{* *} \\
(-2.08)\end{array}$ & $\begin{array}{l}0.056 \\
(0.61)\end{array}$ & $\begin{array}{l}-0.034 \\
(-0.63)\end{array}$ & $\begin{array}{l}-0.043 \\
(-0.57)\end{array}$ & $\begin{array}{l}0.100 \\
(1.46)\end{array}$ & $\begin{array}{c}0.345^{* *} \\
(2.26)\end{array}$ & $\begin{array}{l}-0.070 \\
(-0.71)\end{array}$ & $\begin{array}{l}0.098 \\
(0.79)\end{array}$ & $\begin{array}{l}-0.026 \\
(-0.22)\end{array}$ & $\begin{array}{l}0.008 \\
(0.22)\end{array}$ & $\begin{array}{l}-0.002 \\
(-0.10)\end{array}$ & $\begin{array}{l}-0.035 \\
(-1.15)\end{array}$ & $\begin{array}{l}-0.001 \\
(-0.01)\end{array}$ \\
\hline$\Delta \ln Y$ & $\begin{array}{l}-0.039 \\
(-1.37)\end{array}$ & $\begin{array}{c}-0.249^{*} \\
(-1.77)\end{array}$ & $\begin{array}{l}0.045 \\
(0.47)\end{array}$ & $\begin{array}{l}-0.006 \\
(-0.14)\end{array}$ & $\begin{array}{l}0.001 \\
(0.01)\end{array}$ & $\begin{array}{c}0.209 * * \\
(2.06)\end{array}$ & $\begin{array}{c}0.332^{*} \\
(1.86)\end{array}$ & $\begin{array}{l}-0.056 \\
(-0.63)\end{array}$ & $\begin{array}{l}0.105 \\
(0.96)\end{array}$ & $\begin{array}{l}0.047 \\
(0.47)\end{array}$ & $\begin{array}{l}0.039 \\
(1.43)\end{array}$ & $\begin{array}{c}0.001 \\
(0.08)\end{array}$ & $\begin{array}{l}-0.035 \\
(-1.46)\end{array}$ & $\begin{array}{l}0.004 \\
(0.07)\end{array}$ \\
\hline $\begin{array}{l}\text { Observations } \\
\text { Adjusted } R^{2}\end{array}$ & $\begin{array}{c}107 \\
0.653\end{array}$ & $\begin{array}{c}107 \\
0.831\end{array}$ & $\begin{array}{c}107 \\
0.759\end{array}$ & $\begin{array}{c}107 \\
0.748\end{array}$ & $\begin{array}{c}107 \\
0.502\end{array}$ & $\begin{array}{c}107 \\
0.791\end{array}$ & $\begin{array}{c}107 \\
0.677\end{array}$ & $\begin{array}{c}107 \\
0.302\end{array}$ & $\begin{array}{c}107 \\
0.784\end{array}$ & $\begin{array}{c}107 \\
0.611\end{array}$ & $\begin{array}{c}107 \\
0.623\end{array}$ & $\begin{array}{c}107 \\
0.594\end{array}$ & $\begin{array}{c}107 \\
0.645\end{array}$ & $\begin{array}{c}107 \\
0.102\end{array}$ \\
\hline & $\mathrm{F}$ & 50 & 51 & 52 & $\mathrm{H}$ & $60 \mathrm{t} 63$ & 64 & $\mathrm{~J}$ & $71 \mathrm{t} 74$ & $\mathrm{~L}$ & M & $\mathrm{N}$ & $\mathrm{O}$ & \\
\hline$\Delta \ln \left(P_{E} / P_{L}\right)$ & $\begin{array}{c}0.019 * * * \\
(8.53)\end{array}$ & $\begin{array}{c}0.026^{* * *} \\
(3.13)\end{array}$ & $\begin{array}{c}0.024^{* * *} \\
(7.06)\end{array}$ & $\begin{array}{c}0.036^{* * *} \\
(10.42)\end{array}$ & $\begin{array}{c}0.046^{* * *} \\
(11.26)\end{array}$ & $\begin{array}{c}0.134^{* * *} \\
\quad(6.99)\end{array}$ & $\begin{array}{c}0.018^{* *} \\
(2.06)\end{array}$ & $\begin{array}{c}0.013^{* * *} \\
(8.70)\end{array}$ & $\begin{array}{c}0.020^{* * *} \\
(7.05)\end{array}$ & $\begin{array}{c}0.013^{* *} \\
(2.29)\end{array}$ & $\begin{array}{c}0.020^{* * *} \\
(7.20)\end{array}$ & $\begin{array}{c}0.015^{* * *} \\
(5.58)\end{array}$ & $\begin{array}{c}0.037^{* * *} * \\
\quad(8.07)\end{array}$ & \\
\hline$\Delta \ln \left(K_{I C T} / Y\right)$ & $\begin{array}{l}0.000 \\
(0.11)\end{array}$ & $\begin{array}{l}0.001 \\
(0.14)\end{array}$ & $\begin{array}{l}0.010 \\
(1.49)\end{array}$ & $\begin{array}{l}0.005 \\
(0.49)\end{array}$ & $\begin{array}{c}-0.016^{*} \\
(-1.85)\end{array}$ & $\begin{array}{c}-0.076^{* * *} \\
(-3.27)\end{array}$ & $\begin{array}{l}-0.009 \\
(-0.52)\end{array}$ & $\begin{array}{l}-0.003 \\
(-0.96)\end{array}$ & $\begin{array}{l}-0.003 \\
(-1.09)\end{array}$ & $\begin{array}{l}0.008 \\
(0.55)\end{array}$ & $\begin{array}{l}-0.009 \\
(-1.65)\end{array}$ & $\begin{array}{l}-0.005 \\
(-1.23)\end{array}$ & $\begin{array}{c}-0.018^{* *} \\
(-2.63)\end{array}$ & \\
\hline$\Delta \ln \left(K_{N} / Y\right)$ & $\begin{array}{l}0.004 \\
(0.52)\end{array}$ & $\begin{array}{l}0.001 \\
(0.02)\end{array}$ & $\begin{array}{c}-0.049^{* *} \\
(-2.40)\end{array}$ & $\begin{array}{c}-0.057^{* *} \\
(-2.41)\end{array}$ & $\begin{array}{l}0.012 \\
(0.30)\end{array}$ & $\begin{array}{c}0.209^{* *} \\
(2.27)\end{array}$ & $\begin{array}{l}-0.003 \\
(-0.07)\end{array}$ & $\begin{array}{l}0.001 \\
(0.12)\end{array}$ & $\begin{array}{l}0.002 \\
(0.28)\end{array}$ & $\begin{array}{l}-0.048 \\
(-0.60)\end{array}$ & $\begin{array}{l}0.018 \\
(1.00)\end{array}$ & $\begin{array}{c}-0.054^{* *} \\
(-2.13)\end{array}$ & $\begin{array}{c}-0.032^{* *} \\
(-2.29)\end{array}$ & \\
\hline$\Delta \ln Y$ & $\begin{array}{l}0.005 \\
(0.81)\end{array}$ & $\begin{array}{l}0.026 \\
(0.62)\end{array}$ & $\begin{array}{c}-0.044^{*} \\
(-1.92)\end{array}$ & $\begin{array}{c}-0.044^{* *} \\
(-2.09)\end{array}$ & $\begin{array}{l}-0.023 \\
(-0.59)\end{array}$ & $\begin{array}{c}0.427^{* * *} \\
\quad(4.48)\end{array}$ & $\begin{array}{l}-0.029 \\
(-0.73)\end{array}$ & $\begin{array}{l}-0.007 \\
(-1.40)\end{array}$ & $\begin{array}{c}-0.018^{* *} \\
(-1.99)\end{array}$ & $\begin{array}{l}0.034 \\
(0.35)\end{array}$ & $\begin{array}{l}0.009 \\
(0.46)\end{array}$ & $\begin{array}{c}-0.057^{* *} \\
(-2.40)\end{array}$ & $\begin{array}{l}-0.034 \\
(-1.56)\end{array}$ & \\
\hline Observations & 107 & 107 & 107 & 107 & 107 & 107 & 107 & 107 & 107 & 107 & 107 & 107 & 107 & \\
\hline Adjusted $R^{2}$ & 0.703 & 0.188 & 0.501 & 0.803 & 0.815 & 0.837 & 0.325 & 0.766 & 0.714 & 0.446 & 0.616 & 0.689 & 0.733 & \\
\hline
\end{tabular}

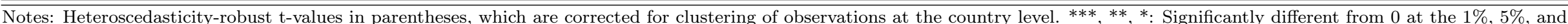
$10 \%$ levels, respectively. The dependent variable is the change in the energy cost share of a country-industry entity for a given year $t$. All regressions are weighted by the country-industry specific average hours worked by persons engaged. All specifications are estimated using the Least Squares Dummy Variable estimator (LSDV). Specification names denote industry codes (NACE 1.1). 
Table 9: Robustness Checks IV - Total Energy - R\&D, Skills, and Trade

\begin{tabular}{|c|c|c|c|c|c|c|c|c|c|c|}
\hline & (1) & $(2)$ & $(3)$ & (4) & $(5)$ & (6) & $(7)$ & (8) & (9) & (10) \\
\hline$\Delta \ln \left(P_{E} / P_{L}\right)$ & $\begin{array}{c}0.063^{* * *} \\
(9.05)\end{array}$ & $\begin{array}{c}0.064^{* * *} \\
(9.63)\end{array}$ & $\begin{array}{c}0.053^{* * *} \\
(8.99)\end{array}$ & $\begin{array}{c}0.053^{* * *} \\
(9.04)\end{array}$ & $\begin{array}{c}0.053^{* * *} \\
(8.47)\end{array}$ & $\begin{array}{c}0.053^{* * *} \\
(9.04)\end{array}$ & $\begin{array}{c}0.053^{* * *} \\
(8.87)\end{array}$ & $\begin{array}{c}0.067^{* * *} \\
(8.91)\end{array}$ & $\begin{array}{c}0.070^{* * *} \\
(10.86)\end{array}$ & $\begin{array}{c}0.069^{* * *} \\
(9.41)\end{array}$ \\
\hline$\Delta \ln \left(K_{I C T} / Y\right)$ & $\begin{array}{c}-0.029^{* *} \\
(-2.95)\end{array}$ & $\begin{array}{c}-0.029^{* *} \\
(-2.89)\end{array}$ & $\begin{array}{c}-0.014^{* * *} \\
(-6.57)\end{array}$ & $\begin{array}{c}-0.014^{* * *} \\
(-6.43)\end{array}$ & $\begin{array}{c}-0.014^{* * *} \\
(-4.79)\end{array}$ & $\begin{array}{c}-0.014^{* * * *} \\
(-6.50)\end{array}$ & $\begin{array}{c}-0.014^{* * *} \\
(-6.25)\end{array}$ & $\begin{array}{c}-0.032^{* *} \\
(-2.86)\end{array}$ & $\begin{array}{c}-0.032^{* *} \\
(-2.65)\end{array}$ & $\begin{array}{c}-0.019^{* *} \\
(-3.24)\end{array}$ \\
\hline$\Delta \ln \left(K_{N} / Y\right)$ & $\begin{array}{c}0.026 \\
(1.23)\end{array}$ & $\begin{array}{l}0.031 \\
(1.31)\end{array}$ & $\begin{array}{l}0.010 \\
(0.88)\end{array}$ & $\begin{array}{l}0.010 \\
(0.89)\end{array}$ & $\begin{array}{l}0.010 \\
(0.80)\end{array}$ & $\begin{array}{l}0.011 \\
(0.91)\end{array}$ & $\begin{array}{l}0.010 \\
(0.92)\end{array}$ & $\begin{array}{l}0.037 \\
(1.47)\end{array}$ & $\begin{array}{l}0.045 \\
(1.62)\end{array}$ & $\begin{array}{c}-0.019^{*} \\
(-2.12)\end{array}$ \\
\hline$\Delta \ln Y$ & $\begin{array}{c}0.057^{* *} \\
(3.39)\end{array}$ & $\begin{array}{c}0.060^{* * *} \\
(3.52)\end{array}$ & $\begin{array}{c}0.039^{* * *} \\
(3.88)\end{array}$ & $\begin{array}{c}0.039^{* * *} \\
(3.93)\end{array}$ & $\begin{array}{c}0.039^{* * *} \\
(3.64)\end{array}$ & $\begin{array}{c}0.039^{* * *} \\
(3.84)\end{array}$ & $\begin{array}{c}0.039^{* * *} \\
(3.84)\end{array}$ & $\begin{array}{c}0.070^{* * *} \\
(4.84)\end{array}$ & $\begin{array}{c}0.074^{* * *} \\
(6.07)\end{array}$ & $\begin{array}{l}0.015 \\
(1.11)\end{array}$ \\
\hline $\ln (R \& D / Y)$ & & $\begin{array}{l}-0.002 \\
(-1.30)\end{array}$ & & & & & & & $\begin{array}{l}-0.002 \\
(-1.24)\end{array}$ & $\begin{array}{l}-0.000 \\
(-0.01)\end{array}$ \\
\hline$\Delta S_{H S}$ & & & & $\begin{array}{l}-0.015 \\
(-1.19)\end{array}$ & & & & & $\begin{array}{l}-0.034 \\
(-1.30)\end{array}$ & $\begin{array}{l}-0.049^{*} \\
(-2.17)\end{array}$ \\
\hline$\Delta \ln (I M P / Y)$ & & & & & $\begin{array}{l}-0.000 \\
(-0.01)\end{array}$ & & & & & \\
\hline$\Delta \ln (E X P / Y)$ & & & & & & $\begin{array}{c}-0.001^{*} \\
(-2.20)\end{array}$ & & & & \\
\hline$\Delta \ln ((E X P+I M P) / Y)$ & & & & & & & $\begin{array}{l}-0.001 \\
(-0.60)\end{array}$ & & $\begin{array}{c}-0.005^{* *} \\
(-3.08)\end{array}$ & $\begin{array}{c}-0.007^{* * *} \\
(-8.64)\end{array}$ \\
\hline Year DVs & Yes & Yes & Yes & Yes & Yes & Yes & Yes & Yes & Yes & Yes \\
\hline Count $\times$ Ind DVs & Yes & Yes & Yes & Yes & Yes & Yes & Yes & Yes & Yes & No \\
\hline Observations & 1418 & 1418 & 2241 & 2241 & 2241 & 2241 & 2241 & 1189 & 1189 & 1189 \\
\hline Adjusted $R^{2}$ & 0.379 & 0.381 & 0.379 & 0.379 & 0.378 & 0.379 & 0.379 & 0.391 & 0.395 & 0.404 \\
\hline
\end{tabular}

Notes: Heteroscedasticity-robust t-values in parentheses, which are corrected for clustering of observations at the country level. ***,**,*. Significantly different from 0 at the $1 \%, 5 \%$, and $10 \%$ levels, respectively. The dependent variable is the change in the energy cost share of a country-industry entity for a given year $t$. All regressions are weighted by the country-industry specific average hours worked by persons engaged. All specifications are estimated using the Least Squares Dummy Variable estimator (LSDV). 
Table 10: Robustness Checks V - Total Energy - Difference-GMM Estimates

\begin{tabular}{|c|c|c|c|c|}
\hline & \multicolumn{2}{|c|}{ Static Specification } & \multicolumn{2}{|c|}{ Dynamic Specification } \\
\hline & $(\mathrm{t}-3 / 5)$ & $(\mathrm{t}-4 / 6)$ & $(\mathrm{t}-3 / 5)$ & $(\mathrm{t}-4 / 6)$ \\
\hline$\Delta \ln \left(P_{E} / P_{L}\right)$ & $\begin{array}{c}0.050 * * * \\
(8.01)\end{array}$ & $\begin{array}{c}0.050^{* * *} \\
(7.53)\end{array}$ & $\begin{array}{c}0.052^{* * *} \\
(7.28)\end{array}$ & $\begin{array}{c}0.053^{* * *} \\
(6.89)\end{array}$ \\
\hline$\Delta \ln \left(K_{I C T} / Y\right)$ & $\begin{array}{l}-0.009 \\
(-0.81)\end{array}$ & $\begin{array}{l}-0.023 \\
(-1.48)\end{array}$ & $\begin{array}{c}-0.039^{*} \\
(-1.84)\end{array}$ & $\begin{array}{c}-0.037^{*} \\
(-1.78)\end{array}$ \\
\hline$\Delta \ln \left(K_{N} / Y\right)$ & $\begin{array}{c}0.036 \\
(1.47)\end{array}$ & $\begin{array}{c}0.087^{* *} \\
(2.08)\end{array}$ & $\begin{array}{r}0.027 \\
(0.89)\end{array}$ & $\begin{array}{c}0.076^{* *} \\
(1.99)\end{array}$ \\
\hline$\Delta \ln Y$ & $\begin{array}{c}0.070^{* * *} \\
(2.88)\end{array}$ & $\begin{array}{c}0.076^{* *} \\
(2.25)\end{array}$ & $\begin{array}{c}0.066^{*} \\
(1.90)\end{array}$ & $\begin{array}{c}0.100^{* *} \\
(2.14)\end{array}$ \\
\hline L. $\Delta S_{E}$ & & & $\begin{array}{c}-0.164^{*} \\
(-1.91)\end{array}$ & $\begin{array}{c}-0.225^{* * *} \\
(-3.33)\end{array}$ \\
\hline L. $\Delta \ln \left(P_{E} / P_{L}\right)$ & & & $\begin{array}{c}0.001 \\
(0.21)\end{array}$ & $\begin{array}{r}0.007 \\
(1.44)\end{array}$ \\
\hline L. $\Delta \ln \left(K_{I C T} / Y\right)$ & & & $\begin{array}{l}0.009 \\
(0.46)\end{array}$ & $\begin{array}{l}-0.016 \\
(-0.75)\end{array}$ \\
\hline L. $\Delta \ln \left(K_{N} / Y\right)$ & & & $\begin{array}{l}0.021 \\
(0.50)\end{array}$ & $\begin{array}{c}0.046 \\
(1.26)\end{array}$ \\
\hline L. $\Delta \ln Y$ & & & $\begin{array}{l}0.053 \\
(1.39)\end{array}$ & $\begin{array}{l}0.058 \\
(1.60)\end{array}$ \\
\hline Year DVs & Yes & Yes & Yes & Yes \\
\hline Observations & 2592 & 2592 & 2295 & 2295 \\
\hline $\mathrm{N}$ of IVs & 107.000 & 95.000 & 130.000 & 115.000 \\
\hline Hansen & 0.053 & 0.077 & 0.092 & 0.009 \\
\hline $\mathrm{AR}(1)$ & $-5.248 * * *$ & $-5.140 * * *$ & $-3.265^{* * *}$ & $-3.418^{* * *}$ \\
\hline $\operatorname{AR}(2)$ & -0.836 & -1.017 & $-2.293^{* *}$ & $-3.123^{* * *}$ \\
\hline $\operatorname{AR}(3)$ & -0.152 & -0.031 & 0.075 & -0.095 \\
\hline
\end{tabular}

Notes: Heteroscedasticity- and autocorrelation-robust t-values in parentheses ***, **, *: Significantly different from 0 at the $1 \%, 5 \%$, and $10 \%$ levels, respectively. The dependent variable is the change in the energy cost share of a country-industry entity for a given year $t$. All regressions are weighted by the country-industry specific average hours worked by persons engaged. All specifications are estimated using the Difference-GMM estimator. We use two-step estimator and employ Windmeijer's finite-sample correction. $(t-3 / 5)$ indicates that the set of instruments includes lagged levels of $\Delta S_{E}, \Delta \ln \left(P_{E} / P_{L}\right)$, $\Delta \ln \left(K_{I C T} / Y\right), \Delta \ln \left(K_{N} / Y\right)$ and $\Delta \ln Y$ dated $t-3, t-4$ and $t-5$. 'N of IVs' indicates the total number of instruments used. $A R(i)$ : Arellano and Bond (1991) test for $H_{0}$ of no residual serial correlation (test statistic). Hansen: Hansen test for $H_{0}$ of joint validity of the instruments (p-value). 


\section{Electric and Non-Electric Energy Tables}

Table 11: Robustness Checks VI - Electric and Non-Electric Energy - Sample Splits

\begin{tabular}{|c|c|c|c|c|c|c|}
\hline & $\begin{array}{l}\mathrm{W} / \mathrm{o} \text { ICT- } \\
\text { Intensive } \\
\text { Industries }\end{array}$ & $\begin{array}{l}\text { W/o Energy- } \\
\text { Intensive } \\
\text { Industries }\end{array}$ & $\begin{array}{c}\text { W/o Public } \\
\text { Services }\end{array}$ & $\begin{array}{l}\text { W/o US, } \\
\text { JPN }\end{array}$ & $\begin{array}{c}\text { Pre } \\
2002\end{array}$ & $\begin{array}{l}\text { Past } \\
2001\end{array}$ \\
\hline & (1) & $(2)$ & $(3)$ & (4) & $(5)$ & $(6)$ \\
\hline \multicolumn{7}{|l|}{$\Delta S_{\text {Elec }}$} \\
\hline$\Delta \ln \left(P_{\text {NElec }} / P_{L}\right)$ & $\begin{array}{c}-0.001^{* *} \\
(-2.25)\end{array}$ & $\begin{array}{c}-0.001^{* *} \\
(-2.52)\end{array}$ & $\begin{array}{l}-0.001 \\
(-1.59)\end{array}$ & $\begin{array}{l}-0.001 \\
(-1.59)\end{array}$ & $\begin{array}{c}-0.002^{* *} \\
(-2.36)\end{array}$ & $\begin{array}{c}-0.002^{* *} \\
(-2.23)\end{array}$ \\
\hline$\Delta \ln \left(P_{\text {Elec }} / P_{L}\right)$ & $\begin{array}{c}0.021^{* * *} \\
(27.42)\end{array}$ & $\begin{array}{c}0.019^{* * *} \\
(26.55)\end{array}$ & $\begin{array}{c}0.021^{* * *} \\
(26.60)\end{array}$ & $\begin{array}{c}0.016^{* * *} \\
(19.09)\end{array}$ & $\begin{array}{c}0.021^{* * *} \\
(21.79)\end{array}$ & $\begin{array}{c}0.022^{* * *} \\
(18.54)\end{array}$ \\
\hline$\Delta \ln \left(K_{I C T} / Y\right)$ & $\begin{array}{l}0.001 \\
(0.60)\end{array}$ & $\begin{array}{l}0.001 \\
(0.56)\end{array}$ & $\begin{array}{l}0.002 \\
(1.11)\end{array}$ & $\begin{array}{c}0.002^{*} \\
(1.75)\end{array}$ & $\begin{array}{l}0.001 \\
(0.50)\end{array}$ & $\begin{array}{l}0.003 \\
(1.12)\end{array}$ \\
\hline$\Delta \ln \left(K_{N} / Y\right)$ & $\begin{array}{l}-0.005 \\
(-1.16)\end{array}$ & $\begin{array}{l}-0.001 \\
(-0.33)\end{array}$ & $\begin{array}{l}0.004 \\
(1.11)\end{array}$ & $\begin{array}{l}-0.001 \\
(-0.40)\end{array}$ & $\begin{array}{l}0.001 \\
(0.11)\end{array}$ & $\begin{array}{c}-0.009^{*} \\
(-1.84)\end{array}$ \\
\hline$\Delta \ln Y$ & $\begin{array}{l}0.001 \\
(0.24) \\
\end{array}$ & $\begin{array}{c}0.007^{*} \\
(1.88)\end{array}$ & $\begin{array}{c}0.011^{* * * *} \\
(3.11)\end{array}$ & $\begin{array}{l}0.004 \\
(1.01)\end{array}$ & $\begin{array}{l}0.006 \\
(1.16) \\
\end{array}$ & $\begin{array}{l}-0.001 \\
(-0.10)\end{array}$ \\
\hline$\Delta S_{N \text { Elec }}$ & & & & & & \\
\hline$\Delta \ln \left(P_{N \text { Elec }} / P_{L}\right)$ & $\begin{array}{c}0.038^{* * * *} \\
(29.55)\end{array}$ & $\begin{array}{c}0.028^{* * *} \\
(31.72)\end{array}$ & $\begin{array}{c}0.041^{* * *} \\
(30.63)\end{array}$ & $\begin{array}{c}0.036^{* * *} \\
(26.85)\end{array}$ & $\begin{array}{c}0.027^{* * *} \\
(15.02)\end{array}$ & $\begin{array}{c}0.042^{* * *} \\
(26.98)\end{array}$ \\
\hline$\Delta \ln \left(P_{\text {Elec }} / P_{L}\right)$ & $\begin{array}{c}-0.001^{* *} \\
(-2.25)\end{array}$ & $\begin{array}{c}-0.001^{* *} \\
(-2.52)\end{array}$ & $\begin{array}{l}-0.001 \\
(-1.59)\end{array}$ & $\begin{array}{l}-0.001 \\
(-1.59)\end{array}$ & $\begin{array}{c}-0.002^{* *} \\
(-2.36)\end{array}$ & $\begin{array}{c}-0.002^{* *} \\
(-2.23)\end{array}$ \\
\hline$\Delta \ln \left(K_{I C T} / Y\right)$ & $\begin{array}{c}-0.016^{* * *} \\
(-5.26)\end{array}$ & $\begin{array}{c}-0.006^{* * *} \\
(-2.82)\end{array}$ & $\begin{array}{c}-0.015^{* * *} \\
(-4.86)\end{array}$ & $\begin{array}{c}-0.013^{* * *} \\
(-4.09)\end{array}$ & $\begin{array}{c}-0.014^{* * *} \\
(-4.01)\end{array}$ & $\begin{array}{c}-0.014^{* *} \\
(-2.45)\end{array}$ \\
\hline$\Delta \ln \left(K_{N} / Y\right)$ & $\begin{array}{l}-0.001 \\
(-0.14)\end{array}$ & $\begin{array}{l}0.000 \\
(0.03)\end{array}$ & $\begin{array}{l}0.012 \\
(1.50)\end{array}$ & $\begin{array}{l}0.002 \\
(0.25)\end{array}$ & $\begin{array}{l}-0.015 \\
(-1.37)\end{array}$ & $\begin{array}{l}0.010 \\
(0.80)\end{array}$ \\
\hline$\Delta \ln Y$ & $\begin{array}{c}0.041^{* * * *} \\
(4.78)\end{array}$ & $\begin{array}{l}0.007 \\
(1.38)\end{array}$ & $\begin{array}{c}0.043^{* * *} \\
(5.77)\end{array}$ & $\begin{array}{c}0.062^{* * * *} \\
(6.91)\end{array}$ & $\begin{array}{l}0.012 \\
(1.25)\end{array}$ & $\begin{array}{c}0.033^{* *} \\
(2.51)\end{array}$ \\
\hline Year & Yes & Yes & Yes & Yes & Yes & Yes \\
\hline Count $\times$ Ind DVs & Yes & Yes & Yes & Yes & Yes & Yes \\
\hline Observations & 2461 & 2461 & 2461 & 2268 & 1593 & 1296 \\
\hline$R_{1}^{2}$ & 0.421 & 0.405 & 0.411 & 0.406 & 0.461 & 0.531 \\
\hline$R_{2}^{\frac{1}{2}}$ & 0.414 & 0.415 & 0.420 & 0.402 & 0.315 & 0.529 \\
\hline
\end{tabular}

Notes: Heteroscedasticity-robust t-values in parentheses, which are corrected for clustering of observations at the country level. ***,**,*: Significantly different from 0 at the $1 \%, 5 \%$, and $10 \%$ levels, respectively. The dependent variable is the change in the energy cost share of a country-industry entity for a given year $t$. All regressions are weighted by the country-industry specific average hours worked by persons engaged. All specifications are estimated by using the iterated Seemingly Unrelated Regression (ISUR). ICT-intensive industries include NACE 30t33, 64, J, and 71t74. Energy-intensive include NACE AtB, C, 60t63, and 26. Public services include NACE L, M, N, and O. 
Table 12: Robustness Checks VII - Electric and Non-Electric Energy - Sectoral Split

\begin{tabular}{|c|c|c|c|c|c|c|}
\hline & \multicolumn{3}{|c|}{ Manufacturing Sector } & \multicolumn{3}{|c|}{ Service Sector } \\
\hline & (1) & $(2)$ & $(3)$ & $(4)$ & (5) & (6) \\
\hline \multicolumn{7}{|l|}{$\Delta S_{\text {Elec }}$} \\
\hline \multirow{2}{*}{$\Delta \ln \left(P_{N \text { Elec }} / P_{L}\right)$} & $-0.004^{* * *}$ & $-0.004^{* * *}$ & $-0.004^{* * *}$ & 0.000 & 0.000 & 0.000 \\
\hline & $(-3.67)$ & $(-3.76)$ & $(-3.74)$ & $(0.33)$ & $(0.16)$ & $(0.21)$ \\
\hline \multirow{2}{*}{$\Delta \ln \left(P_{\text {Elec }} / P_{L}\right)$} & $0.051^{* * *}$ & $0.049^{* * *}$ & $0.049^{* * *}$ & $0.012^{* * *}$ & $0.011^{* * *}$ & $0.011^{* * *}$ \\
\hline & $(31.23)$ & $(30.99)$ & $(31.17)$ & $(21.11)$ & $(20.37)$ & $(20.27)$ \\
\hline \multirow[t]{2}{*}{$\Delta \ln \left(K_{I C T} / Y\right)$} & -0.001 & -0.003 & -0.001 & 0.001 & -0.000 & 0.000 \\
\hline & $(-0.34)$ & $(-0.75)$ & $(-0.29)$ & $(0.84)$ & $(-0.14)$ & $(0.18)$ \\
\hline \multirow[t]{2}{*}{$\Delta \ln \left(K_{N} / Y\right)$} & -0.010 & 0.002 & $-0.009^{* *}$ & -0.001 & -0.000 & $-0.004^{*}$ \\
\hline & $(-1.41)$ & $(0.21)$ & $(-1.98)$ & $(-0.39)$ & $(-0.02)$ & $(-1.80)$ \\
\hline \multirow[t]{2}{*}{$\Delta \ln Y$} & 0.006 & 0.011 & & 0.002 & 0.005 & \\
\hline & $(1.05)$ & $(1.21)$ & & $(0.99)$ & $(1.59)$ & \\
\hline \multicolumn{7}{|l|}{$\Delta S_{N E l e c}$} \\
\hline \multirow{2}{*}{$\Delta \ln \left(P_{\text {NElec }} / P_{L}\right)$} & $0.052^{* * *}$ & $0.053^{* * *}$ & $0.053^{* * *}$ & $0.015^{* * *}$ & $0.014^{* * *}$ & $0.014^{* * *}$ \\
\hline & $(29.55)$ & $(29.62)$ & $(29.76)$ & $(21.83)$ & $(21.62)$ & $(21.65)$ \\
\hline \multirow[t]{2}{*}{$\Delta \ln \left(P_{\text {Elec }} / P_{L}\right)$} & $-0.004^{* * *}$ & $-0.004^{* * *}$ & $-0.004^{* * *}$ & 0.000 & 0.000 & 0.000 \\
\hline & $(-3.67)$ & $(-3.76)$ & $(-3.74)$ & $(0.33)$ & $(0.16)$ & $(0.21)$ \\
\hline \multirow[t]{2}{*}{$\Delta \ln \left(K_{I C T} / Y\right)$} & -0.006 & $-0.013^{* *}$ & $-0.010^{*}$ & -0.001 & -0.002 & -0.002 \\
\hline & $(-1.21)$ & $(-2.02)$ & $(-1.65)$ & $(-0.63)$ & $(-1.34)$ & $(-1.51)$ \\
\hline \multirow[t]{2}{*}{$\Delta \ln \left(K_{N} / Y\right)$} & -0.009 & 0.009 & -0.009 & -0.000 & 0.002 & 0.004 \\
\hline & $(-0.86)$ & $(0.55)$ & $(-1.25)$ & $(-0.19)$ & $(0.51)$ & $(1.51)$ \\
\hline \multirow[t]{2}{*}{$\Delta \ln Y$} & 0.002 & 0.017 & & $-0.005^{*}$ & -0.003 & \\
\hline & $(0.24)$ & $(1.23)$ & & $(-1.91)$ & $(-0.67)$ & \\
\hline Year & Yes & Yes & Yes & Yes & Yes & Yes \\
\hline Observations & 1284 & 1284 & 1284 & 1177 & 1177 & 1177 \\
\hline$R_{1}^{2}$ & 0.508 & 0.586 & 0.585 & 0.398 & 0.483 & 0.482 \\
\hline$R_{2}^{2}$ & 0.494 & 0.518 & 0.517 & 0.514 & 0.556 & 0.556 \\
\hline
\end{tabular}

Notes: Heteroscedasticity-robust t-values in parentheses, which are corrected for clustering of observations at the country level. ***,**, *: Significantly different from 0 at the $1 \%, 5 \%$, and $10 \%$ levels, respectively. The dependent variable is the change in the energy cost share of a country-industry entity for a given year $t$. All regressions are weighted by the country-industry specific average hours worked by persons engaged. All specifications are estimated by using the iterated Seemingly Unrelated Regression (ISUR). 
Table 13: Robustness Checks VIII - Electric and Non-Electric Energy - Industry Specific Estimates (Part I)

\begin{tabular}{|c|c|c|c|c|c|c|c|c|c|c|c|c|c|c|}
\hline & AtB & $\mathrm{C}$ & $15 \mathrm{t} 16$ & $17 \mathrm{t} 19$ & 20 & $21 \mathrm{t} 22$ & 24 & 25 & 26 & $27 \mathrm{t} 28$ & 29 & $30 \mathrm{t} 33$ & $34 \mathrm{t} 35$ & $36 \mathrm{t} 37$ \\
\hline \multicolumn{15}{|l|}{$\overline{\Delta S_{\text {Elec }}}$} \\
\hline$\Delta \ln \left(P_{\text {NElec }} / P_{L}\right)$ & $\begin{array}{c}0.001 \\
(0.38)\end{array}$ & $\begin{array}{l}-0.007 \\
(-1.57)\end{array}$ & $\begin{array}{l}-0.001 \\
(-0.67)\end{array}$ & $\begin{array}{l}-0.003 \\
(-1.48)\end{array}$ & $\begin{array}{c}-0.011^{* *} \\
(-2.38)\end{array}$ & $\begin{array}{c}-0.011^{* * *} \\
(-3.02)\end{array}$ & $\begin{array}{c}-0.017^{* * *} \\
(-4.64)\end{array}$ & $\begin{array}{l}0.001 \\
(0.07)\end{array}$ & $\begin{array}{c}-0.020^{* * *} \\
(-4.31)\end{array}$ & $\begin{array}{c}-0.013^{* * *} \\
(-4.76)\end{array}$ & $\begin{array}{c}0.003^{*} \\
(1.82)\end{array}$ & $\begin{array}{l}0.000 \\
(0.03)\end{array}$ & $\begin{array}{c}-0.006^{* * *} \\
(-2.91)\end{array}$ & $\begin{array}{c}0.000 \\
(0.10)\end{array}$ \\
\hline$\Delta \ln \left(P_{\text {Elec }} / P_{L}\right)$ & $\begin{array}{c}0.014^{* * *} \\
(8.06)\end{array}$ & $\begin{array}{c}0.065^{* * *} \\
(10.27)\end{array}$ & $\begin{array}{c}0.037^{* * *} \\
(18.06)\end{array}$ & $\begin{array}{c}0.039^{* * *} \\
(12.87)\end{array}$ & $\begin{array}{c}0.060^{* * *} \\
(11.14)\end{array}$ & $\begin{array}{c}0.071^{* * *} \\
(14.71)\end{array}$ & $\begin{array}{c}0.106^{* * *} \\
(18.15)\end{array}$ & $\begin{array}{c}0.066^{* * *} \\
(6.62)\end{array}$ & $\begin{array}{c}0.080^{* * *} \\
(16.37)\end{array}$ & $\begin{array}{c}0.089^{* * *} \\
(21.05)\end{array}$ & $\begin{array}{c}0.017^{* * *} \\
(9.57)\end{array}$ & $\begin{array}{c}0.020^{* * *} \\
(11.76)\end{array}$ & $\begin{array}{c}0.035^{* * *} \\
(15.04)\end{array}$ & $\begin{array}{c}0.024^{* * *} \\
(5.97)\end{array}$ \\
\hline$\Delta \ln \left(K_{I C T} / Y\right)$ & $\begin{array}{l}-0.000 \\
(-0.14)\end{array}$ & $\begin{array}{l}-0.006 \\
(-0.52)\end{array}$ & $\begin{array}{l}-0.003 \\
(-0.44)\end{array}$ & $\begin{array}{c}-0.018^{* * *} \\
(-2.86)\end{array}$ & $\begin{array}{c}0.004 \\
(0.34)\end{array}$ & $\begin{array}{l}-0.018 \\
(-1.56)\end{array}$ & $\begin{array}{l}-0.011 \\
(-0.78)\end{array}$ & $\begin{array}{l}0.018 \\
(0.57)\end{array}$ & $\begin{array}{l}-0.006 \\
(-0.52)\end{array}$ & $\begin{array}{l}-0.004 \\
(-0.37)\end{array}$ & $\begin{array}{l}-0.005 \\
(-1.01)\end{array}$ & $\begin{array}{l}-0.000 \\
(-0.01)\end{array}$ & $\begin{array}{l}-0.006 \\
(-1.26)\end{array}$ & $\begin{array}{c}0.009 \\
(0.88)\end{array}$ \\
\hline$\Delta \ln \left(K_{N} / Y\right)$ & $\begin{array}{l}-0.001 \\
(-0.22)\end{array}$ & $\begin{array}{l}-0.039 \\
(-0.86)\end{array}$ & $\begin{array}{l}0.004 \\
(0.16)\end{array}$ & $\begin{array}{l}0.007 \\
(0.43)\end{array}$ & $\begin{array}{l}0.001 \\
(0.02)\end{array}$ & $\begin{array}{l}0.056 \\
(1.38)\end{array}$ & $\begin{array}{c}0.091^{*} \\
(1.92)\end{array}$ & $\begin{array}{l}-0.084 \\
(-1.34)\end{array}$ & $\begin{array}{l}0.019 \\
(0.57)\end{array}$ & $\begin{array}{l}0.056 \\
(1.54)\end{array}$ & $\begin{array}{c}0.018 \\
(1.23)\end{array}$ & $\begin{array}{l}-0.004 \\
(-0.43)\end{array}$ & $\begin{array}{l}-0.015 \\
(-1.21)\end{array}$ & $\begin{array}{l}0.004 \\
(0.10)\end{array}$ \\
\hline$\Delta \ln Y$ & $\begin{array}{l}-0.004 \\
(-0.54)\end{array}$ & $\begin{array}{l}-0.031 \\
(-0.69)\end{array}$ & $\begin{array}{l}-0.008 \\
(-0.29)\end{array}$ & $\begin{array}{l}0.006 \\
(0.39)\end{array}$ & $\begin{array}{l}0.025 \\
(0.64)\end{array}$ & $\begin{array}{c}0.076^{*} \\
(1.79)\end{array}$ & $\begin{array}{l}0.061 \\
(1.37)\end{array}$ & $\begin{array}{l}-0.022 \\
(-0.42)\end{array}$ & $\begin{array}{l}0.030 \\
(0.94)\end{array}$ & $\begin{array}{l}0.023 \\
(0.75)\end{array}$ & $\begin{array}{l}0.014 \\
(1.33)\end{array}$ & $\begin{array}{c}0.001 \\
(0.11)\end{array}$ & $\begin{array}{c}-0.024^{* *} \\
(-2.54)\end{array}$ & $\begin{array}{l}0.033 \\
(1.08)\end{array}$ \\
\hline \multicolumn{15}{|l|}{$\overline{\Delta S_{N E l e c}}$} \\
\hline$\Delta \ln \left(P_{N \text { Elec }} / P_{L}\right)$ & $\begin{array}{c}0.052^{* * *} \\
(10.49)\end{array}$ & $\begin{array}{c}0.080^{* * *} \\
(8.75)\end{array}$ & $\begin{array}{c}0.068^{* * *} \\
(16.58)\end{array}$ & $\begin{array}{c}0.055^{* * *} \\
(20.15)\end{array}$ & $\begin{array}{l}0.006 \\
(1.34)\end{array}$ & $\begin{array}{c}0.062^{* * *} \\
(13.08)\end{array}$ & $\begin{array}{c}0.104^{* * *} \\
(12.24)\end{array}$ & $\begin{array}{l}-0.007 \\
(-1.03)\end{array}$ & $\begin{array}{c}0.147^{* * *} \\
(12.92)\end{array}$ & $\begin{array}{c}0.079^{* * *} \\
(14.76)\end{array}$ & $\begin{array}{c}0.037^{* * *} \\
(13.53)\end{array}$ & $\begin{array}{c}0.021^{* * *} \\
(8.71)\end{array}$ & $\begin{array}{c}0.012^{* * *} \\
(6.33)\end{array}$ & $\begin{array}{c}-0.010^{* * *} \\
(-3.57)\end{array}$ \\
\hline$\Delta \ln \left(P_{\text {Elec }} / P_{L}\right)$ & $\begin{array}{l}0.005 \\
(0.78)\end{array}$ & $\begin{array}{l}-0.011 \\
(-0.78)\end{array}$ & $\begin{array}{c}-0.016^{* * *} \\
(-3.01)\end{array}$ & $\begin{array}{c}-0.013^{* * *} \\
(-2.97)\end{array}$ & $\begin{array}{c}0.018^{* * *} \\
(3.20)\end{array}$ & $\begin{array}{l}-0.000 \\
(-0.04)\end{array}$ & $\begin{array}{l}0.009 \\
(0.66)\end{array}$ & $\begin{array}{c}0.027^{* * *} \\
(2.90)\end{array}$ & $\begin{array}{c}-0.040^{* * *} \\
(-3.26)\end{array}$ & $\begin{array}{c}-0.019^{* *} \\
(-2.40)\end{array}$ & $\begin{array}{c}-0.006^{*} \\
(-1.72)\end{array}$ & $\begin{array}{l}0.001 \\
(0.44)\end{array}$ & $\begin{array}{c}0.005^{* * *} \\
(2.83)\end{array}$ & $\begin{array}{c}0.015^{* * *} \\
(4.05)\end{array}$ \\
\hline$\Delta \ln \left(K_{I C T} / Y\right)$ & $\begin{array}{l}-0.011 \\
(-1.12)\end{array}$ & $\begin{array}{l}-0.017 \\
(-0.76)\end{array}$ & $\begin{array}{l}-0.015 \\
(-1.01)\end{array}$ & $\begin{array}{l}-0.003 \\
(-0.27)\end{array}$ & $\begin{array}{l}-0.008 \\
(-0.74)\end{array}$ & $\begin{array}{l}-0.004 \\
(-0.28)\end{array}$ & $\begin{array}{c}-0.080^{* *} \\
(-2.28)\end{array}$ & $\begin{array}{l}-0.026 \\
(-0.92)\end{array}$ & $\begin{array}{l}-0.005 \\
(-0.17)\end{array}$ & $\begin{array}{l}-0.020 \\
(-0.94)\end{array}$ & $\begin{array}{l}0.009 \\
(0.97)\end{array}$ & $\begin{array}{l}0.008 \\
(0.98)\end{array}$ & $\begin{array}{l}0.001 \\
(0.21)\end{array}$ & $\begin{array}{l}-0.014 \\
(-1.48)\end{array}$ \\
\hline$\Delta \ln \left(K_{N} / Y\right)$ & $\begin{array}{l}-0.008 \\
(-0.46)\end{array}$ & $\begin{array}{c}-0.245^{* *} \\
(-2.51)\end{array}$ & $\begin{array}{l}0.013 \\
(0.20)\end{array}$ & $\begin{array}{c}-0.062^{* *} \\
(-2.54)\end{array}$ & $\begin{array}{l}0.045 \\
(1.04)\end{array}$ & $\begin{array}{l}0.048 \\
(0.89)\end{array}$ & $\begin{array}{c}0.207^{*} \\
(1.82)\end{array}$ & $\begin{array}{l}0.074 \\
(1.29)\end{array}$ & $\begin{array}{l}0.016 \\
(0.21)\end{array}$ & $\begin{array}{l}-0.094 \\
(-1.37)\end{array}$ & $\begin{array}{l}-0.030 \\
(-1.11)\end{array}$ & $\begin{array}{l}-0.009 \\
(-0.58)\end{array}$ & $\begin{array}{l}-0.009 \\
(-0.90)\end{array}$ & $\begin{array}{c}0.060^{*} \\
(1.97)\end{array}$ \\
\hline$\Delta \ln Y$ & $\begin{array}{l}-0.029 \\
(-1.24)\end{array}$ & $\begin{array}{c}-0.206^{* *} \\
(-2.15)\end{array}$ & $\begin{array}{l}-0.004 \\
(-0.06)\end{array}$ & $\begin{array}{l}-0.034 \\
(-1.55)\end{array}$ & $\begin{array}{c}0.069^{*} \\
(1.70)\end{array}$ & $\begin{array}{c}0.125^{* *} \\
(2.22)\end{array}$ & $\begin{array}{c}0.210^{* *} \\
(1.98)\end{array}$ & $\begin{array}{l}0.046 \\
(0.94)\end{array}$ & $\begin{array}{l}-0.003 \\
(-0.03)\end{array}$ & $\begin{array}{l}-0.037 \\
(-0.62)\end{array}$ & $\begin{array}{c}0.004 \\
(0.18)\end{array}$ & $\begin{array}{l}-0.003 \\
(-0.28)\end{array}$ & $\begin{array}{l}-0.011 \\
(-1.41)\end{array}$ & $\begin{array}{l}0.046^{*} \\
(1.67)\end{array}$ \\
\hline Observations & 107 & 107 & 107 & 107 & 107 & 107 & 107 & 107 & 107 & 107 & 107 & 107 & 107 & 107 \\
\hline Adjusted $R_{1}^{2}$ & 0.725 & 0.765 & 0.865 & 0.811 & 0.753 & 0.791 & 0.846 & 0.647 & 0.813 & 0.870 & 0.729 & 0.838 & 0.810 & 0.500 \\
\hline Adjusted $R_{2}^{2}$ & 0.742 & 0.852 & 0.820 & 0.868 & 0.475 & 0.799 & 0.750 & 0.157 & 0.768 & 0.800 & 0.718 & 0.572 & 0.710 & 0.425 \\
\hline
\end{tabular}

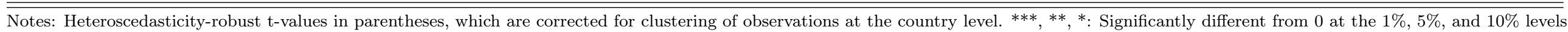

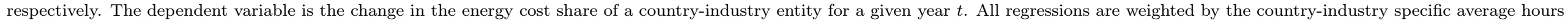
worked by persons engaged. All specifications are estimated by using the iterated Seemingly Unrelated Regression (ISUR). 
Table 14: Robustness Checks VIII - Electric and Non-Electric Energy - Industry Specific Estimates (Part II)

\begin{tabular}{|c|c|c|c|c|c|c|c|c|c|c|c|c|c|}
\hline & $\mathrm{F}$ & 50 & 51 & 52 & $\mathrm{H}$ & $60 \mathrm{t} 63$ & 64 & $\mathrm{~J}$ & $71 \mathrm{t} 74$ & $\mathrm{~L}$ & M & $\mathrm{N}$ & $\mathrm{O}$ \\
\hline \multicolumn{14}{|l|}{$\overline{\Delta S_{\text {Elec }}}$} \\
\hline$\Delta \ln \left(P_{\text {NElec }} / P_{L}\right)$ & $\begin{array}{c}0.003^{* *} \\
(2.06)\end{array}$ & $\begin{array}{l}-0.002 \\
(-1.48)\end{array}$ & $\begin{array}{l}-0.001 \\
(-1.22)\end{array}$ & $\begin{array}{c}0.001 \\
(0.51)\end{array}$ & $\begin{array}{l}-0.003 \\
(-1.49)\end{array}$ & $\begin{array}{c}0.000 \\
(0.14)\end{array}$ & $\begin{array}{l}-0.001 \\
(-0.35)\end{array}$ & $\begin{array}{l}0.001 \\
(0.62)\end{array}$ & $\begin{array}{l}-0.001 \\
(-0.61)\end{array}$ & $\begin{array}{c}-0.004^{* *} \\
(-2.27)\end{array}$ & $\begin{array}{l}-0.000 \\
(-0.09)\end{array}$ & $\begin{array}{c}-0.002^{*} \\
(-1.85)\end{array}$ & $\begin{array}{l}-0.004 \\
(-1.32)\end{array}$ \\
\hline$\Delta \ln \left(P_{\text {Elec }} / P_{L}\right)$ & $\begin{array}{l}0.002 \\
(1.59)\end{array}$ & $\begin{array}{c}0.015^{* * *} \\
(11.21)\end{array}$ & $\begin{array}{c}0.007^{* * *} \\
(8.99)\end{array}$ & $\begin{array}{c}0.013^{* * *} \\
(6.41)\end{array}$ & $\begin{array}{c}0.024^{* * *} \\
(9.93)\end{array}$ & $\begin{array}{c}0.012^{* * *} \\
(10.94)\end{array}$ & $\begin{array}{c}0.016^{* * *} \\
(6.50)\end{array}$ & $\begin{array}{c}0.004^{* * *} \\
(6.06)\end{array}$ & $\begin{array}{c}0.006^{* * *} \\
(7.26)\end{array}$ & $\begin{array}{c}0.015^{* * *} \\
(6.93)\end{array}$ & $\begin{array}{c}0.009^{* * *} \\
(4.55)\end{array}$ & $\begin{array}{c}0.011^{* * *} \\
(8.16)\end{array}$ & $\begin{array}{c}0.018^{* * *} \\
(8.17)\end{array}$ \\
\hline$\Delta \ln \left(K_{I C T} / Y\right)$ & $\begin{array}{c}0.006^{* * *} \\
(3.35)\end{array}$ & $\begin{array}{l}-0.003 \\
(-1.25)\end{array}$ & $\begin{array}{c}0.001 \\
(0.57)\end{array}$ & $\begin{array}{c}0.004 \\
(0.71)\end{array}$ & $\begin{array}{c}-0.011^{* *} \\
(-2.15)\end{array}$ & $\begin{array}{c}0.008^{* * *} \\
(3.98)\end{array}$ & $\begin{array}{l}-0.003 \\
(-0.68)\end{array}$ & $\begin{array}{l}0.002 \\
(1.47)\end{array}$ & $\begin{array}{l}-0.000 \\
(-0.25)\end{array}$ & $\begin{array}{c}-0.012^{*} \\
(-1.90)\end{array}$ & $\begin{array}{c}0.000 \\
(0.02)\end{array}$ & $\begin{array}{c}0.002 \\
(0.59)\end{array}$ & $\begin{array}{l}-0.003 \\
(-0.63)\end{array}$ \\
\hline$\Delta \ln \left(K_{N} / Y\right)$ & $\begin{array}{c}0.014^{* * *} \\
(3.14)\end{array}$ & $\begin{array}{l}0.009 \\
(0.72)\end{array}$ & $\begin{array}{c}-0.013^{* *} \\
(-2.04)\end{array}$ & $\begin{array}{l}-0.030 \\
(-1.61)\end{array}$ & $\begin{array}{l}0.012 \\
(0.48)\end{array}$ & $\begin{array}{c}-0.013^{*} \\
(-1.89)\end{array}$ & $\begin{array}{c}0.004 \\
(0.30)\end{array}$ & $\begin{array}{l}0.004 \\
(1.01)\end{array}$ & $\begin{array}{l}-0.002 \\
(-0.57)\end{array}$ & $\begin{array}{l}-0.021 \\
(-1.18)\end{array}$ & $\begin{array}{l}0.003 \\
(0.21)\end{array}$ & $\begin{array}{c}-0.035^{* * *} \\
(-2.85)\end{array}$ & $\begin{array}{c}-0.029^{* * *} \\
(-2.84)\end{array}$ \\
\hline$\Delta \ln Y$ & $\begin{array}{c}0.010^{* *} \\
(2.35)\end{array}$ & $\begin{array}{l}0.016 \\
(1.32)\end{array}$ & $\begin{array}{c}-0.012^{* *} \\
(-2.03)\end{array}$ & $\begin{array}{l}-0.005 \\
(-0.31)\end{array}$ & $\begin{array}{l}-0.012 \\
(-0.48)\end{array}$ & $\begin{array}{l}-0.009 \\
(-1.15)\end{array}$ & $\begin{array}{l}-0.003 \\
(-0.25)\end{array}$ & $\begin{array}{l}0.002 \\
(0.61)\end{array}$ & $\begin{array}{l}-0.003 \\
(-0.76)\end{array}$ & $\begin{array}{c}0.038^{*} \\
(1.71)\end{array}$ & $\begin{array}{l}0.007 \\
(0.44)\end{array}$ & $\begin{array}{c}-0.051^{* * *} \\
(-3.94)\end{array}$ & $\begin{array}{l}-0.010 \\
(-0.64)\end{array}$ \\
\hline \multicolumn{14}{|l|}{$\overline{\Delta S_{N E l e c}}$} \\
\hline$\Delta \ln \left(P_{\text {NElec }} / P_{L}\right)$ & $\begin{array}{c}0.015^{* * *} \\
(7.88)\end{array}$ & $\begin{array}{c}0.007^{* *} \\
(2.04)\end{array}$ & $\begin{array}{c}0.016^{* * *} \\
(4.33)\end{array}$ & $\begin{array}{c}0.020^{* * *} \\
(13.27)\end{array}$ & $\begin{array}{c}0.026^{* * *} \\
(17.05)\end{array}$ & $\begin{array}{c}0.138^{* * *} \\
(7.33)\end{array}$ & $\begin{array}{c}0.009^{* *} \\
(2.19)\end{array}$ & $\begin{array}{c}0.008^{* * *} \\
(10.19)\end{array}$ & $\begin{array}{c}0.011^{* * *} \\
(6.78)\end{array}$ & $\begin{array}{c}0.010^{* * *} \\
(3.97)\end{array}$ & $\begin{array}{c}0.007^{* * *} \\
(4.75)\end{array}$ & $\begin{array}{c}0.007^{* * *} \\
(6.70)\end{array}$ & $\begin{array}{c}0.017^{* * *} \\
(8.46)\end{array}$ \\
\hline$\Delta \ln \left(P_{\text {Elec }} / P_{L}\right)$ & $\begin{array}{l}-0.000 \\
(-0.23)\end{array}$ & $\begin{array}{c}0.011^{* * *} \\
(3.46)\end{array}$ & $\begin{array}{l}-0.000 \\
(-0.01)\end{array}$ & $\begin{array}{c}0.001 \\
(0.46)\end{array}$ & $\begin{array}{c}0.000 \\
(0.04)\end{array}$ & $\begin{array}{l}-0.013 \\
(-1.29)\end{array}$ & $\begin{array}{c}0.002 \\
(0.51)\end{array}$ & $\begin{array}{c}0.000 \\
(0.39)\end{array}$ & $\begin{array}{c}0.003^{* *} \\
(2.54)\end{array}$ & $\begin{array}{c}-0.006^{*} \\
(-1.96)\end{array}$ & $\begin{array}{c}0.004^{* * *} \\
(3.21)\end{array}$ & $\begin{array}{c}0.003^{* * *} \\
(2.99)\end{array}$ & $\begin{array}{c}0.004^{* *} \\
(2.33)\end{array}$ \\
\hline$\Delta \ln \left(K_{I C T} / Y\right)$ & $\begin{array}{c}-0.005^{* *} \\
(-2.02)\end{array}$ & $\begin{array}{c}0.000 \\
(0.04)\end{array}$ & $\begin{array}{c}0.008 \\
(0.85)\end{array}$ & $\begin{array}{c}0.003 \\
(0.56)\end{array}$ & $\begin{array}{l}-0.000 \\
(-0.01)\end{array}$ & $\begin{array}{c}-0.082^{* * *} \\
(-4.30)\end{array}$ & $\begin{array}{l}-0.008 \\
(-1.02)\end{array}$ & $\begin{array}{c}-0.004^{* * *} \\
(-2.74)\end{array}$ & $\begin{array}{c}-0.005^{*} \\
(-1.87)\end{array}$ & $\begin{array}{c}0.015^{*} \\
(1.85)\end{array}$ & $\begin{array}{c}-0.007^{* *} \\
(-2.44)\end{array}$ & $\begin{array}{c}-0.006^{* *} \\
(-2.43)\end{array}$ & $\begin{array}{c}-0.008^{* * *} \\
(-2.61)\end{array}$ \\
\hline$\Delta \ln \left(K_{N} / Y\right)$ & $\begin{array}{l}-0.009 \\
(-1.36)\end{array}$ & $\begin{array}{l}-0.014 \\
(-0.47)\end{array}$ & $\begin{array}{l}-0.035 \\
(-1.45)\end{array}$ & $\begin{array}{c}-0.032^{* *} \\
(-2.02)\end{array}$ & $\begin{array}{l}-0.006 \\
(-0.33)\end{array}$ & $\begin{array}{c}0.228^{* * *} \\
(3.32)\end{array}$ & $\begin{array}{l}-0.014 \\
(-0.71)\end{array}$ & $\begin{array}{l}-0.002 \\
(-0.62)\end{array}$ & $\begin{array}{c}0.008 \\
(1.55)\end{array}$ & $\begin{array}{l}-0.025 \\
(-1.08)\end{array}$ & $\begin{array}{l}0.001 \\
(0.10)\end{array}$ & $\begin{array}{c}0.003 \\
(0.28)\end{array}$ & $\begin{array}{c}-0.014^{*} \\
(-1.90)\end{array}$ \\
\hline$\Delta \ln Y$ & $\begin{array}{l}-0.003 \\
(-0.54)\end{array}$ & $\begin{array}{l}-0.006 \\
(-0.23)\end{array}$ & $\begin{array}{l}-0.032 \\
(-1.34)\end{array}$ & $\begin{array}{c}-0.033^{* *} \\
(-2.26)\end{array}$ & $\begin{array}{l}0.001 \\
(0.05)\end{array}$ & $\begin{array}{c}0.430^{* * *} \\
(6.05)\end{array}$ & $\begin{array}{l}-0.027 \\
(-1.25)\end{array}$ & $\begin{array}{c}-0.007^{* *} \\
(-2.11)\end{array}$ & $\begin{array}{l}-0.004 \\
(-0.65)\end{array}$ & $\begin{array}{l}-0.002 \\
(-0.08)\end{array}$ & $\begin{array}{l}-0.004 \\
(-0.42)\end{array}$ & $\begin{array}{l}0.002 \\
(0.21)\end{array}$ & $\begin{array}{c}-0.031^{* * *} \\
(-2.83)\end{array}$ \\
\hline Observations & 107 & 107 & 107 & 107 & 107 & 107 & 107 & 107 & 107 & 107 & 107 & 107 & 107 \\
\hline Adjusted $R_{1}^{2}$ & 0.572 & 0.707 & 0.721 & 0.702 & 0.710 & 0.764 & 0.540 & 0.710 & 0.585 & 0.682 & 0.477 & 0.647 & 0.611 \\
\hline Adjusted $R_{2}^{2}$ & 0.772 & 0.293 & 0.544 & 0.855 & 0.880 & 0.861 & 0.485 & 0.835 & 0.746 & 0.679 & 0.534 & 0.798 & 0.814 \\
\hline
\end{tabular}

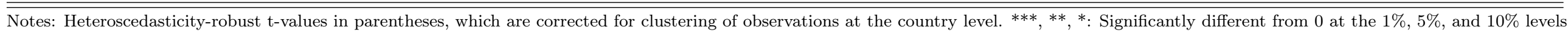

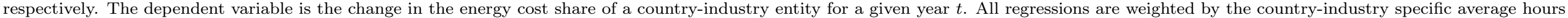
worked by persons engaged. All specifications are estimated by using the iterated Seemingly Unrelated Regression (ISUR). 
Table 15: Robustness Checks VIII - Electric and Non-Electric Energy - R\&D, Skills, and Trade

\begin{tabular}{|c|c|c|c|c|c|c|c|}
\hline & (1) & $(2)$ & $(3)$ & (4) & $(5)$ & $(6)$ & $(7)$ \\
\hline \multicolumn{8}{|l|}{$\Delta S_{\text {Elec }}$} \\
\hline$\Delta \ln \left(P_{N \text { Elec }} / P_{L}\right)$ & $\begin{array}{l}-0.001 \\
(-1.42)\end{array}$ & $\begin{array}{l}-0.001 \\
(-1.25)\end{array}$ & $\begin{array}{c}-0.002^{* * *} \\
(-3.29)\end{array}$ & $\begin{array}{c}-0.002^{* * *} \\
(-3.29)\end{array}$ & $\begin{array}{c}-0.002^{* * *} \\
(-3.15)\end{array}$ & $\begin{array}{c}-0.002^{*} \\
(-1.92)\end{array}$ & $\begin{array}{l}-0.002 \\
(-1.51)\end{array}$ \\
\hline$\Delta \ln \left(P_{\text {Elec }} / P_{L}\right)$ & $\begin{array}{c}0.025^{* * *} \\
(19.76)\end{array}$ & $\begin{array}{c}0.025^{* * *} \\
(19.78)\end{array}$ & $\begin{array}{c}0.023^{* * *} \\
(26.34)\end{array}$ & $\begin{array}{c}0.023^{* * *} \\
(26.33)\end{array}$ & $\begin{array}{c}0.023^{* * *} \\
(25.57)\end{array}$ & $\begin{array}{c}0.027^{* * *} \\
(17.27)\end{array}$ & $\begin{array}{c}0.027^{* * *} \\
(16.47)\end{array}$ \\
\hline$\Delta \ln \left(K_{I C T} / Y\right)$ & $\begin{array}{c}0.001 \\
(0.22)\end{array}$ & $\begin{array}{c}0.001 \\
(0.21)\end{array}$ & $\begin{array}{l}-0.001 \\
(-0.33)\end{array}$ & $\begin{array}{l}-0.001 \\
(-0.32)\end{array}$ & $\begin{array}{l}-0.001 \\
(-0.34)\end{array}$ & $\begin{array}{l}-0.001 \\
(-0.22)\end{array}$ & $\begin{array}{l}-0.001 \\
(-0.24)\end{array}$ \\
\hline$\Delta \ln \left(K_{N} / Y\right)$ & $\begin{array}{c}0.005 \\
(0.85)\end{array}$ & $\begin{array}{c}0.006 \\
(1.02)\end{array}$ & $\begin{array}{c}0.002 \\
(0.37)\end{array}$ & $\begin{array}{c}0.002 \\
(0.37)\end{array}$ & $\begin{array}{c}0.002 \\
(0.35)\end{array}$ & $\begin{array}{c}0.005 \\
(0.65)\end{array}$ & $\begin{array}{c}0.006 \\
(0.87)\end{array}$ \\
\hline$\Delta \ln Y$ & $\begin{array}{c}0.012^{* *} \\
(2.09)\end{array}$ & $\begin{array}{c}0.012^{* *} \\
(2.22)\end{array}$ & $\begin{array}{c}0.007^{*} \\
(1.86)\end{array}$ & $\begin{array}{c}0.007^{*} \\
(1.86)\end{array}$ & $\begin{array}{c}0.007^{*} \\
(1.88)\end{array}$ & $\begin{array}{c}0.011^{*} \\
(1.76)\end{array}$ & $\begin{array}{c}0.012^{*} \\
(1.95)\end{array}$ \\
\hline $\ln (R \& D / Y)$ & & $\begin{array}{l}-0.000 \\
(-1.32)\end{array}$ & & & & & $\begin{array}{l}-0.000 \\
(-1.46)\end{array}$ \\
\hline$\Delta S_{H S}$ & & & & $\begin{array}{l}0.002 \\
(0.34)\end{array}$ & & & $\begin{array}{l}-0.000 \\
(-0.05)\end{array}$ \\
\hline$\Delta \ln ((E X P+I M P) / Y)$ & & & & & $\begin{array}{c}0.001 \\
(0.89)\end{array}$ & & $\begin{array}{l}0.000 \\
(0.12)\end{array}$ \\
\hline \multicolumn{8}{|l|}{$\overline{\Delta S_{N E l e c}}$} \\
\hline$\Delta \ln \left(P_{\text {NElec }} / P_{L}\right)$ & $\begin{array}{c}0.046^{* * *} \\
(24.35)\end{array}$ & $\begin{array}{c}0.047^{* * *} \\
(24.46)\end{array}$ & $\begin{array}{c}0.040^{* * *} \\
(29.23)\end{array}$ & $\begin{array}{c}0.040^{* * *} \\
(29.31)\end{array}$ & $\begin{array}{c}0.040^{* * *} \\
(29.27)\end{array}$ & $\begin{array}{c}0.050 * * * \\
(23.26)\end{array}$ & $\begin{array}{c}0.052^{* * *} \\
(23.72)\end{array}$ \\
\hline$\Delta \ln \left(P_{\text {Elec }} / P_{L}\right)$ & $\begin{array}{l}-0.001 \\
(-1.42)\end{array}$ & $\begin{array}{l}-0.001 \\
(-1.25)\end{array}$ & $\begin{array}{c}-0.002^{* * *} \\
(-3.29)\end{array}$ & $\begin{array}{c}-0.002^{* * *} \\
(-3.29)\end{array}$ & $\begin{array}{c}-0.002^{* * *} \\
(-3.15)\end{array}$ & $\begin{array}{c}-0.002^{*} \\
(-1.92)\end{array}$ & $\begin{array}{l}-0.002 \\
(-1.51)\end{array}$ \\
\hline$\Delta \ln \left(K_{I C T} / Y\right)$ & $\begin{array}{c}-0.025^{* * *} \\
(-5.09)\end{array}$ & $\begin{array}{c}-0.025 * * * \\
(-5.12)\end{array}$ & $\begin{array}{c}-0.011 * * * \\
(-3.27)\end{array}$ & $\begin{array}{c}-0.011^{* * *} \\
(-3.32)\end{array}$ & $\begin{array}{c}-0.011^{* * *} \\
(-3.25)\end{array}$ & $\begin{array}{c}-0.024^{* * *} \\
(-4.38)\end{array}$ & $\begin{array}{c}-0.024^{* * *} \\
(-4.29)\end{array}$ \\
\hline$\Delta \ln \left(K_{N} / Y\right)$ & $\begin{array}{l}0.018 \\
(1.51)\end{array}$ & $\begin{array}{c}0.022^{*} \\
(1.82)\end{array}$ & $\begin{array}{r}0.006 \\
(0.63)\end{array}$ & $\begin{array}{l}0.006 \\
(0.63)\end{array}$ & $\begin{array}{l}0.006 \\
(0.65)\end{array}$ & $\begin{array}{l}0.024 \\
(1.63)\end{array}$ & $\begin{array}{c}0.030^{* *} \\
(2.03)\end{array}$ \\
\hline$\Delta \ln Y$ & $\begin{array}{c}0.044^{* * *} \\
(4.23)\end{array}$ & $\begin{array}{c}0.047^{* * *} \\
(4.47)\end{array}$ & $\begin{array}{c}0.032^{* * *} \\
(4.06)\end{array}$ & $\begin{array}{c}0.032^{* * *} \\
(4.07)\end{array}$ & $\begin{array}{c}0.032^{* * *} \\
(3.99)\end{array}$ & $\begin{array}{c}0.054^{* * *} \\
(4.36)\end{array}$ & $\begin{array}{c}0.057^{* * *} * \\
(4.54)\end{array}$ \\
\hline $\ln (R \& D / Y)$ & & $\begin{array}{c}-0.001^{* *} \\
(-2.41)\end{array}$ & & & & & $\begin{array}{c}-0.001^{* * *} \\
(-2.61)\end{array}$ \\
\hline$\Delta S_{H S}$ & & & & $\begin{array}{c}-0.020^{*} \\
(-1.88)\end{array}$ & & & $\begin{array}{c}-0.051^{* *} \\
(-2.64)\end{array}$ \\
\hline$\Delta \ln ((E X P+I M P) / Y)$ & & & & & $\begin{array}{l}-0.002 \\
(-1.50)\end{array}$ & & $\begin{array}{c}-0.005^{*} \\
(-1.95)\end{array}$ \\
\hline Year DVs & Yes & Yes & Yes & Yes & Yes & Yes & Yes \\
\hline Count $\times$ Ind DVs & Yes & Yes & Yes & Yes & Yes & Yes & Yes \\
\hline Observations & 1418 & 1418 & 2241 & 2241 & 2241 & 1189 & 1189 \\
\hline$R_{1}^{2}$ & 0.409 & 0.410 & 0.441 & 0.441 & 0.441 & 0.419 & 0.421 \\
\hline$R_{2}^{2}$ & 0.444 & 0.447 & 0.426 & 0.427 & 0.426 & 0.466 & 0.473 \\
\hline
\end{tabular}

Notes: Heteroscedasticity-robust t-values in parentheses, which are corrected for clustering of observations at the country level. $* * *, * *, *$ : Significantly different from 0 at the $1 \%, 5 \%$, and $10 \%$ levels, respectively. The dependent variable is the change in the energy cost share of a country-industry entity for a given year $t$. All regressions are weighted by the country-industry specific average hours worked by persons engaged. All specifications are estimated by using the iterated Seemingly Unrelated Regression (ISUR). 
Table 16: Robustness Checks IX - Electric and Non-Electric Energy - Difference-GMM Estimates

\begin{tabular}{|c|c|c|c|c|c|c|c|c|}
\hline & \multicolumn{4}{|c|}{ Electricity Equation } & \multicolumn{4}{|c|}{ Non-Electric Energy Equation } \\
\hline & \multicolumn{2}{|c|}{ Static } & \multicolumn{2}{|c|}{ Dynamic } & \multicolumn{2}{|c|}{ Static } & \multicolumn{2}{|c|}{ Dynamic } \\
\hline & $(\mathrm{t}-3 / 5)$ & $(\mathrm{t}-4 / 6)$ & $(\mathrm{t}-3 / 5)$ & $(\mathrm{t}-4 / 6)$ & $(\mathrm{t}-3 / 5)$ & $(\mathrm{t}-4 / 6)$ & $(\mathrm{t}-3 / 5)$ & $(\mathrm{t}-4 / 6)$ \\
\hline$\Delta \ln \left(P_{\text {Elec }} / P_{L}\right)$ & $\begin{array}{c}0.017^{* * *} \\
(7.99)\end{array}$ & $\begin{array}{c}0.017^{* * *} \\
(8.00)\end{array}$ & $\begin{array}{c}0.019^{* * *} \\
(8.16)\end{array}$ & $\begin{array}{c}0.018^{* * * *} \\
(8.32)\end{array}$ & $\begin{array}{l}-0.001 \\
(-0.35)\end{array}$ & $\begin{array}{l}-0.004 \\
(-1.49)\end{array}$ & $\begin{array}{l}-0.001 \\
(-0.37)\end{array}$ & $\begin{array}{l}-0.005 \\
(-1.54)\end{array}$ \\
\hline$\Delta \ln \left(P_{N \text { Elec }} / P_{L}\right)$ & $\begin{array}{c}-0.002^{*} \\
(-1.72)\end{array}$ & $\begin{array}{l}-0.002 \\
(-1.16)\end{array}$ & $\begin{array}{l}-0.002 \\
(-1.10)\end{array}$ & $\begin{array}{l}-0.002 \\
(-0.89)\end{array}$ & $\begin{array}{c}0.034^{* * *} \\
(6.95)\end{array}$ & $\begin{array}{c}0.036^{* * *} \\
(6.66)\end{array}$ & $\begin{array}{c}0.035^{* * *} \\
(6.67)\end{array}$ & $\begin{array}{c}0.036^{* * *} \\
(7.85)\end{array}$ \\
\hline$\Delta \ln \left(K_{I C T} / Y\right)$ & $\begin{array}{l}-0.002 \\
(-0.54)\end{array}$ & $\begin{array}{c}0.002 \\
(0.52)\end{array}$ & $\begin{array}{c}0.014^{*} \\
(1.94)\end{array}$ & $\begin{array}{c}0.007 \\
(1.03)\end{array}$ & $\begin{array}{c}-0.020^{* *} \\
(-2.04)\end{array}$ & $\begin{array}{c}-0.026^{* *} \\
(-1.97)\end{array}$ & $\begin{array}{c}-0.033^{* *} \\
(-2.01)\end{array}$ & $\begin{array}{c}-0.034^{* *} \\
(-2.06)\end{array}$ \\
\hline$\Delta \ln \left(K_{N} / Y\right)$ & $\begin{array}{c}0.018^{*} \\
(1.87)\end{array}$ & $\begin{array}{l}0.008 \\
(0.72)\end{array}$ & $\begin{array}{c}0.025^{*} \\
(1.89)\end{array}$ & $\begin{array}{l}0.009 \\
(0.76)\end{array}$ & $\begin{array}{c}0.047^{* *} \\
(2.33)\end{array}$ & $\begin{array}{c}0.062^{*} \\
(1.78)\end{array}$ & $\begin{array}{c}0.023 \\
(1.10)\end{array}$ & $\begin{array}{c}0.015 \\
(0.64)\end{array}$ \\
\hline$\Delta \ln Y$ & $\begin{array}{c}0.027^{* * *} \\
(2.74)\end{array}$ & $\begin{array}{c}0.026^{* * *} \\
(2.64)\end{array}$ & $\begin{array}{c}0.045^{* * *} \\
(3.07)\end{array}$ & $\begin{array}{c}0.028^{* *} \\
(2.46)\end{array}$ & $\begin{array}{c}0.063^{* * *} \\
(2.94)\end{array}$ & $\begin{array}{c}0.046^{*} \\
(1.76)\end{array}$ & $\begin{array}{c}0.054^{*} \\
(1.91)\end{array}$ & $\begin{array}{l}0.051 \\
(1.31)\end{array}$ \\
\hline L. $\Delta S_{\text {Elec }}$ & & & $\begin{array}{c}-0.274^{* * *} \\
(-4.66)\end{array}$ & $\begin{array}{c}-0.196^{* * *} \\
(-3.37)\end{array}$ & & & & \\
\hline L. $\Delta \ln \left(P_{\text {Elec }} / P_{L}\right)$ & & & $\begin{array}{c}0.003^{* *} \\
(2.11)\end{array}$ & $\begin{array}{l}0.001 \\
(0.65)\end{array}$ & & & $\begin{array}{l}-0.000 \\
(-0.03)\end{array}$ & $\begin{array}{l}-0.002 \\
(-0.67)\end{array}$ \\
\hline L. $\Delta \ln \left(P_{\text {NElec }} / P_{L}\right)$ & & & $\begin{array}{l}0.001 \\
(0.36)\end{array}$ & $\begin{array}{l}0.001 \\
(0.92)\end{array}$ & & & $\begin{array}{c}0.007^{*} \\
(1.74)\end{array}$ & $\begin{array}{c}0.008^{* *} \\
(1.98)\end{array}$ \\
\hline L. $\Delta \ln \left(K_{I C T} / Y\right)$ & & & $\begin{array}{c}-0.014^{* * *} \\
(-2.66)\end{array}$ & $\begin{array}{l}-0.001 \\
(-0.25)\end{array}$ & & & $\begin{array}{l}0.001 \\
(0.08)\end{array}$ & $\begin{array}{l}-0.018 \\
(-0.98)\end{array}$ \\
\hline L. $\Delta \ln \left(K_{N} / Y\right)$ & & & $\begin{array}{c}0.016^{*} \\
(1.71)\end{array}$ & $\begin{array}{l}0.009 \\
(0.83)\end{array}$ & & & $\begin{array}{c}0.033 \\
(1.18)\end{array}$ & $\begin{array}{c}0.063^{*} \\
(1.86)\end{array}$ \\
\hline $\mathrm{L} . \Delta \ln Y$ & & & $\begin{array}{l}-0.015 \\
(-1.64)\end{array}$ & $\begin{array}{l}-0.007 \\
(-0.67)\end{array}$ & & & $\begin{array}{c}0.058^{*} \\
(1.97)\end{array}$ & $\begin{array}{c}0.099^{* *} \\
(2.48)\end{array}$ \\
\hline L. $\Delta S_{N E l e c}$ & & & & & & & $\begin{array}{c}-0.234^{* *} \\
(-2.34)\end{array}$ & $\begin{array}{c}-0.235^{* *} \\
(-2.33)\end{array}$ \\
\hline Year DVs & Yes & Yes & Yes & Yes & Yes & Yes & Yes & Yes \\
\hline Observations & 2592 & 2592 & 2295 & 2295 & 2592 & 2592 & 2295 & 2295 \\
\hline $\mathrm{N}$ of IVs & 131.000 & 116.000 & 154.000 & 136.000 & 131.000 & 116.000 & 154.000 & 136.000 \\
\hline Hansen & 0.008 & 0.020 & 0.029 & 0.032 & 0.052 & 0.026 & 0.237 & 0.297 \\
\hline $\operatorname{AR}(1)$ & $-4.532^{* * *}$ & $-4.617^{* * *}$ & $-3.554^{* * *}$ & $-3.469^{* * *}$ & $-4.420^{* * *}$ & $-4.388^{* * *}$ & $-2.479 * *$ & $-2.465^{* *}$ \\
\hline $\operatorname{AR}(2)$ & $-1.669^{*}$ & $-1.734^{*}$ & $-3.579 * * *$ & $-3.293^{* * *}$ & -0.635 & -0.774 & $-2.142^{* *}$ & $-2.288^{* *}$ \\
\hline $\operatorname{AR}(3)$ & $1.923^{*}$ & $1.916^{*}$ & $0.385^{*}$ & $0.943^{*}$ & -0.158 & -0.100 & 0.081 & 0.317 \\
\hline
\end{tabular}

Notes: Heteroscedasticity- and autocorrelation-robust t-values in parentheses $* * *, * *, *$ : Significantly different from 0 at the $1 \%, 5 \%$, and $10 \%$ levels, respectively. In the electricity equation, the dependent variable is the change in the electric energy cost share of a country-industry entity for a given year $t$. In the non-electric energy equation the dependent variables is the non-electric energy cost share. All regressions are weighted by the country-industry specific average hours worked by persons engaged. All specifications are estimated using the Difference-GMM estimator. We use two-step estimator and employ Windmeijer's finite-sample correction. $(t-3 / 5)$ indicates that the set of instruments includes lagged levels of $\Delta S_{E}, \Delta \ln \left(P_{E} / P_{L}\right), \Delta \ln \left(K_{I C T} / Y\right), \Delta \ln \left(K_{N} / Y\right)$ and $\Delta \ln Y$ dated $t-3, t-4$ and $t-5$. 'N of IVs' indicates the total number of instruments used. $A R(i)$ : Arellano and Bond (1991) test for $H_{0}$ of no residual serial correlation (test statistic). Hansen: Hansen test for $H_{0}$ of joint validity of the instruments (p-value). 


\subsection{Appendix B: Data}

\section{Input and Output Data}

The EU KLEMS database provides capital service indices, but does not contain capital service levels which are comparable across countries and industries. Since in some of our robustness checks we want to compare their levels across countries and industries we have to construct those quantities first. To do so we combine the available capital service indices $(1995=100)$ with the information on capital stocks in 1995 . That is, we construct the capital service quantities as:

$$
K_{k t}=K_{\text {stock }_{k} 95} \times \frac{K_{\text {services }_{k} t}}{100},
$$

where $k \in\{\mathrm{ICT}, \mathrm{N}\}$. Thus, in 1995 we assume capital services to have the same level as the respective capital stocks. In subsequent years the derived capital service quantity grows at the same rate as the capital service index given by EU KLEMS. Labor services are computed in an analogous way by using the 'total hours worked by persons engaged' as starting value for 1995 in combination with the 'labor service volume index' for subsequent years.

\section{Purchasing Power Parities}

To transform nominal values in local currency into real values of a common currency we use purchasing power parities, $P P P_{k, i, 1997}$, denoted in local currency per US dollar, from the GGDC Productivity Level Database in combination with price indices, $P_{k, i, t}$, from the EU KLEMS database. The methodology we apply follows e.g. Inklaar and Timmer (2007, 2009). First, conversion factors, $P P P_{k, i, t}$, are derived for value added (VA), intermediate inputs (II), total capital $(\mathrm{K})$, ICT capital $\left(K_{I C T}\right)$, non-ICT capital $\left(K_{N}\right)$ and labor $(\mathrm{L})$ by

$$
P P P_{k, i, t}=\frac{P_{k, i, 1997}}{P_{k, i, t}} \frac{1}{P P P_{k, i, 1997}},
$$

where $k \in\left\{\mathrm{VA}, \mathrm{II}, \mathrm{K}, K_{I C T}, K_{N}, \mathrm{~L}\right\}, i$ stands for the country-industry combinations available and $t$ denotes time. Multiplying the nominal values with these conversion factors then yields the real values (in real 1997 US dollars).

\section{Energy Quantity Data}

The non-electric energy aggregate consists of the sum of the following energy commodities 
available in the environmental accounts of WIOD: 'hard coal', 'lignite and derivatives', 'coke', 'crude oil, NGL and feedstocks', 'diesel oil for road transport', 'motor gasoline', 'jet fuel', ' light fuel oil', 'heavy fuel oil', 'other petroleum products', 'naphta', 'natural gas', 'derived gas'. The electric energy aggregate consists of: 'electricity'.

\section{Energy Price Data}

The energy price data are taken from the IEA's Energy Prices and Taxes database. It provides energy prices in US dollars per tonne of oil equivalent for 14 different types of energy. These types include: 'steam coal', 'coking coal', 'automotive diesel fuel', 'high sulphur fuel oil', 'light fuel oil', 'low sulphur fuel oil', 'natural gas'. The prices include energy taxes and are calculated by converting national prices using international exchange rates. Prices for three different sectors are published: households, the industrial sector and the electricity generating sector. We use the industrial sector prices. Missing values are replaced with prices from the electricity generating sector (for a similar imputation see Serletis, Timilsina, and Vasetsky (2011)). The energy prices are converted from a tons of oil equivalent (toe) basis into a terajoule (TJ) basis to ensure a common physical unit between price and quantity data. A conversion factor given by the IEA of 1 toe $=0.041868 \mathrm{TJ}$ is applied. For non-electric energy sources the following procedure is applied: first, in order to maximize the number of observations, prices for four different energy carrier groups (coal, petroleum, oil, gas) are generated. The steam coal price is used as the coal price but is replaced by the coking coal price if the steam coal price is not available. For oil, the high sulphur fuel oil price is used as standard but is replaced by low sulphur fuel oil price or the light fuel oil price if necessary. In the case of gas, the natural gas price is used, whereas for petroleum products there is only the automotive diesel fuel price available. Subsequently, these four price approximations are used to price four groups of energy quantities. The coal price is applied to 'hard coal', 'lignite', and 'coke'; the petroleum price is used for 'diesel', 'gasoline', 'jet fuel', 'other petroleum products' and 'naphtha'; the oil price is applied to the 'light fuel oil', 'heavy fuel oil' and 'crude oil' quantities; the gas price is used for 'natural gas' and 'other gases'. The sum of these energy cost values is then divided by the total sum of energy use, which gives the average energy price for a given year and entity. As an alternative, we consider using the oil price alone as non-electric energy price proxy. For electric energy we make use of the given industrial electricity prices and replace them by those of the electricity generating 
sector if prices for the industrial sector are not available.

\section{Trade Data}

Import and export data by sector and year are constructed using the WIOD input-output tables. An import flow into one sector and country by year (in million US dollars) is the sum of all single values of shipments from any sector and country into the respective sector. All within country shipments from the input-output tables are deleted. In a similar fashion, exports are defined as the sum of all shipments from one sector to any other sectors and to all end-use categories in all other countries. Finally, the openness of a sector to international trade is defined as the sum of its total imports and exports scaled by the sector's value added. 
Variable Description and Unit of Measurement

\section{EU KLEMS November 2009 Release}

Gross value added at current basic prices (in millions of national currency)

Real fixed capital stock by asset type (in 1995 prices)

Capital services, volume indices $(1995=100)$

ICT capital services, volume indices $(1995=100)$

Non-ICT capital services, volume indices $(1995=100)$

Capital compensation by asset type (in millions of national currency)

Total hours worked by persons engaged

Labour services, volume indices $(1995=100)$

Labor compensation (in millions of national currency)

Price levels value added $(1995=100)$

Price levels intermediate inputs $(1995=100)$

Price levels of gross fixed capital formation by asset type $(1995=100)$

\section{GGDC Productivity Level Database}

Purchasing Power Parities for country-industry combinations (national currency per US\$, 1997)

\section{World Input-Output Database}

Emission relevant energy use by commodity (in TJ)

Gross energy use by commodity (in TJ)

Use of products by industry at current purchasers prices (in millions of national currency)

Hours worked by high-skilled persons engaged (share in total hours)

\section{IEA Electricity Information Statistics}

Industry sector total price by energy commodity (in US dollar per toe)

Electricity sector total price by energy commodity (in US dollar per toe)

OECD Analytical Business Enterprise Research and Development Database

Expenditures by main activity denoted (in 2005 US dollar) 
Table 18: Variable Description and Units of Measurement

\begin{tabular}{|c|c|}
\hline \multicolumn{2}{|c|}{ Variable Description and Unit of Measurement } \\
\hline \multicolumn{2}{|c|}{ Factor Quantities and Output } \\
\hline$L$ & Labor services in hours worked by persons engaged \\
\hline$E$ & Total emission relevant energy use in TJ \\
\hline Elec & Electric emission relevant energy use in TJ \\
\hline NElec & Non-electric emission relevant energy use in TJ \\
\hline$K$ & Capital services in real 1997 US Dollar (PPP) \\
\hline$K_{N}$ & ICT Capital services in real 1997 US Dollar (PPP) \\
\hline$K_{I C T}$ & Non-ICT capital services in real 1997 US Dollar (PPP) \\
\hline$K_{C O M P}$ & Computing capital services in real 1997 US Dollar (PPP) \\
\hline$K_{C T}$ & Communication equipment capital services in real 1997 US Dollar (PPP) \\
\hline & Value added plus energy intermediate energy expenditures in real 1997 US dollar (PPP) \\
\hline \multicolumn{2}{|c|}{ Flexible Factor Prices } \\
\hline$P_{L}$ & Labor service price in real 1997 US dollar (PPP) per hour worked \\
\hline & Total energy price in real 1997 US dollar per TJ \\
\hline$P_{\text {Elec }}$ & Electric energy price in real 1997 US dollar per TJ \\
\hline$P_{N E l e c}$ & Non-electric energy price in real 1997 US dollar per TJ \\
\hline \multicolumn{2}{|c|}{ Additional Control Variables } \\
\hline$I M P$ & Imports in million real 1997 US dollar (PPP) \\
\hline$E X P$ & Exprots in million real 1997 US dollar (PPP) \\
\hline & Share of high-skilled hours worked within industries \\
\hline$R \& D$ & $R \& D$ expenditures by main activity in 2005 US dollar \\
\hline
\end{tabular}




\begin{tabular}{|c|c|c|c|c|}
\hline Industry & Code & Main & Man. & Serv \\
\hline Agriculture, hunting, forestry, and fishing & AtB & $\mathrm{x}$ & & \\
\hline Mining and quarrying & $\mathrm{C}$ & $\mathrm{x}$ & & \\
\hline Food, beverages and tobacco & $15 \mathrm{t} 16$ & $\mathrm{x}$ & $\mathrm{x}$ & \\
\hline Textiles, textile, leather and footwear & $17 \mathrm{t} 19$ & $\mathrm{x}$ & $\mathrm{x}$ & \\
\hline Wood and wood products & 20 & $\mathrm{x}$ & $\mathrm{x}$ & \\
\hline Pulp, paper, printing and publishing & $21 \mathrm{t} 22$ & $\mathrm{x}$ & $\mathrm{x}$ & \\
\hline Coke, refined petroleum and nuclear fuel & 23 & & & \\
\hline Chemicals and chemical products & 24 & $\mathrm{x}$ & $\mathrm{x}$ & \\
\hline Rubber and plastic products & 25 & $\mathrm{x}$ & $\mathrm{x}$ & \\
\hline Other non-metallic mineral products & 26 & $\mathrm{x}$ & $\mathrm{x}$ & \\
\hline Basic metals and fabricated metal products & $27 \mathrm{t} 28$ & $\mathrm{x}$ & $\mathrm{x}$ & \\
\hline Machinery and equipment, nec & 29 & $\mathrm{x}$ & $\mathrm{x}$ & \\
\hline Electrical and optical equipment & $30 \mathrm{t} 33$ & $\mathrm{x}$ & $\mathrm{x}$ & \\
\hline Transport equipment & $34 \mathrm{t} 35$ & $\mathrm{x}$ & $\mathrm{x}$ & \\
\hline Manufacturing nec, recycling & $36 \mathrm{t} 37$ & $\mathrm{x}$ & $\mathrm{x}$ & \\
\hline Electricity, gas and water supply & $\mathrm{E}$ & & & \\
\hline Construction & $\mathrm{F}$ & $\mathrm{x}$ & & \\
\hline Sale, maint. and repair of motor veh., retail sale of autom. fuel & 50 & $\mathrm{x}$ & & $\mathrm{x}$ \\
\hline Wholesale trade and commission trade, except of motor veh. & 51 & $\mathrm{x}$ & & $\mathrm{x}$ \\
\hline Retail trade, except of motor vehicles & 52 & $\mathrm{x}$ & & $\mathrm{x}$ \\
\hline Hotels and restaurants & $\mathrm{H}$ & $\mathrm{x}$ & & $\mathrm{x}$ \\
\hline Transport and storage & $60 t 63$ & $\mathrm{x}$ & & \\
\hline Post and telecommunications & 64 & $\mathrm{x}$ & & $\mathrm{x}$ \\
\hline Financial intermediation & $\mathrm{J}$ & $\mathrm{x}$ & & $\mathrm{x}$ \\
\hline Real estate activities & 70 & & & \\
\hline Renting of machinery and equipment, other business activities & $71 \mathrm{t} 74$ & $\mathrm{x}$ & & $\mathrm{x}$ \\
\hline Public administration and defence, social security & $\mathrm{L}$ & $\mathrm{x}$ & & $\mathrm{x}$ \\
\hline Education & M & $\mathrm{x}$ & & $\mathrm{x}$ \\
\hline Health and social work & $\mathrm{N}$ & $\mathrm{x}$ & & $\mathrm{x}$ \\
\hline Other community, social and personal services & $\mathrm{O}$ & $\mathrm{x}$ & & $\mathrm{x}$ \\
\hline
\end{tabular}




\subsection{Appendix C: Methods}

Based on the parameters of cost share equations one can derive corresponding factor demand elasticities. Following the approach used by Welsch and Ochsen (2005) or Kratena (2007), one can make use of the fact that factor demand $j$ is equal to $\left(\frac{V C}{P_{j}}\right) S_{j}$ and derive the elasticity of factor demand with respect to a change in the quasi-fixed ICT capital input $\epsilon_{j K_{I C T}}$ :

$$
\epsilon_{j K_{I C T}}=\frac{\partial \ln j}{\partial \ln K_{I C T}}=\frac{\partial \ln \frac{S_{j} V C}{P_{j}}}{\partial \ln K_{I C T}}=\frac{\partial \ln S_{j}}{\partial \ln K_{I C T}}+\frac{\partial \ln V C}{\partial \ln K_{I C T}}-\frac{\partial \ln P_{j}}{\partial \ln K_{I C T}} .
$$

Assuming exogenous prices (which implies $\frac{\partial \ln P_{j}}{\partial \ln K_{I C T}}=0$ ) and using the parameters of the cost share equation, the previous equation equals:

$$
\epsilon_{j K_{I C T}}=\frac{\beta_{K_{I C T}}}{S_{j}}+\frac{\partial \ln V C}{\partial \ln K_{I C T}}-0=\frac{\beta_{K_{I C T}}}{S_{j}}+\frac{\partial V C}{\partial K_{I C T}} \frac{K_{I C T}}{V C},
$$

where $-\frac{\partial V C}{\partial K_{I C T}}$ represents the potential reduction in variable costs through increasing ICT capital by one unit and holding output, variable input prices, and the remaining fixed inputs constant and can be denoted as the shadow value of fixed ICT capital $\left(R_{K_{I C T}}\right)$. Either one assumes that this reduction is negligible and assumes $-\frac{\partial V C}{\partial K_{I C T}}=0$ (see e.g. Hijzen et al. (2005) or Foster et al. (2013)) or one takes this reduction into account. If one takes this reduction into account, the elasticity equals:

$$
\epsilon_{j K_{I C T}}=\frac{\beta_{K_{I C T}}}{S_{j}}-\frac{R_{K_{I C T}} K_{I C T}}{V C} .
$$

Since $\frac{R_{K_{I C T}} K_{I C T}}{V C}$ and $S_{j}$ are larger than zero by definition, $\beta_{K_{I C T}}<0$ is a sufficient condition for $\epsilon_{j K_{I C T}}$ being negative. Thus, $\beta_{K_{I C T}}<0$ implies not only a negative impact on the respective factor cost share (or on the relative demand for the respective factor) but, given output, also on the (absolute) demand for this factor. Following Berndt and Hesse (1986) or Kratena (2007), one can additionally assume that the ex post rate of return for capital equals the shadow price of capital input. Information on the ex post rate of return is typically available in the data. Combining it with the estimated $\beta_{K_{I C T}}$ coefficient, the observed values of the factor cost shares, the capital input quantities and variable costs, then allows to compute the respective elasticities. They equal:

$$
\epsilon_{j K_{I C T}}=\frac{\beta_{K_{I C T}}}{S_{j}}-S_{K_{I C T}}
$$


where $S_{K_{I C T}}=\frac{P_{K_{I C T}} K_{I C T}}{V C}$. This elasticity of demand for factor $j$ with respect to ICT capital describes by how much the respective demand for factor $j$ changes if ICT capital increases by one percent, holding output, the remaining fixed inputs and factor prices constant. Holding output constant implies that this elasticity is also equal to the elasticity describing the impact on the factor intensity $(j / Y)$ and equal to the elasticity describing the impact on the factor productivity $(Y / j)$ multiplied by minus one:

$$
\epsilon_{j K_{I C T}}=\frac{\beta_{K_{I C T}}}{S_{j}}-S_{K_{I C T}}=\frac{\ln (j / Y)}{\ln K_{I C T}}=-\frac{\ln (Y / j)}{\ln K_{I C T}} .
$$

These elasticities hold for all variable input demands $j$, that is, in our case, for labor and energy, or labor, electric and non-electric energy. 